Int. J. Dev. Biol. 64: 181-201 (2020)

https://doi.org/10.1387/ijdb.190285vb

\title{
Epigenetic regulation and transcriptional memory in development; selection facilitating prudence
}

\author{
AKANKSHA VERMA $\$$, JAYANT MAINI\$ ${ }^{\$}$, SHRUTI JAIN\#, MOHSEN GHASEMI"\#, SURBHI KOHLI \\ and VANI BRAHMACHARI* \\ Dr. B.R. Ambedkar Center for Biomedical Research, University of Delhi, Delhi, India
}

\begin{abstract}
The epigenetic mechanisms regulating developmental gene expression are examples of a strategy to generate unique expression profiles with global regulators controlling several genes. In a simplified view, a common set of tools, that include DNA motif recognizing proteins (recruiters), binding/interacting surfaces (ARPs- actin related proteins), epigenetic writers (histone methyltransferases, acetylases), readers (chromatin remodeling proteins, PRC1 members) and erasers (demethylases, deacetylases) form complexes which not only regulate transcription, but also retain the transcriptional memory through mitosis. There are two arms of epigenetic regulation: covalent modification of DNA and the post-translational modification of histones. In this review, we discuss both of these aspects briefly to illustrate functional diversity. We discuss our efforts at utilization of the genome sequence data for de novo identification of new players and their functional validation in this remarkable process.
\end{abstract}

KEY WORDS: epigenetic regulation, cellular memory modules, INO80, PRE/TRE, moonlighting function

\section{Introduction}

The epigenetic regulation of development involves mechanisms that maintain transcriptional status through development and in some cases, establish trans-generational memory. This field has expanded significantly over the years and there are several recent reviews covering this area. In the present review, we provide a brief overview of the DNA sequence elements that are sites for recruitment of protein complexes and the trans-factors that are recruited to these sites to create a context for the area of our research interest and our contribution in this area.

The development of organisms from fertilized egg to an adult is one of the most efficient and well canalized transcription circuits (Davidson et al., 2002). A transcription circuit consists of genes with spatially and temporally controlled expression, often as a cascade of regulators and targets resulting in a unique transcriptional profile for each of the developmentally committed lineage. The transcriptional circuits are maintained by global regulators, often in the absence of the initial stimulus resulting in the switching on and off of the genes. This is achieved by epigenetic mechanisms that flag the genes for activation or repression via modification of DNAand post-translational modification of the histones which form an integral part of the Cellular Memory Modules (CMM) (Razin and Riggs, 1980; Ringrose and Paro, 2004).

The CMMs consist of the cis-elements that act as recruitment sites for the multi-protein complexes on the chromatin (Fig. 1). Their role in development was first recognized in Drosophila. Currently, such modules are identified across phyla and are implicated in a variety of biological processes and diseases, including $X$ chromosome inactivation and tumorigenesis (Henikoff and Greally, 2016; Table 1). There are two arms of epigenetic regulation: the covalent modification of the DNA and the post-translational modification of histones. In the current review, we discuss the epigenetic mechanisms of gene regulation in development. The major focus will be on DNA methylation; histone modification brought about by Polycomb/Trithorax Group Proteins and the associated responsive DNA elements. We discuss our work on the role of chromatin remodeler, INO80 as an Enhancer of Polycomb and Trithorax protein (ETP).

Abbreviations used in this paper: $5 \mathrm{hmC}, 5$ hydroxymethyl cytosine; $5 \mathrm{mC}, 5$ methyl cytosine: ARP, actin related protein; DNMT, DNA methyltransferase; ETP, enhancer of polycomb and trithorax protein; MLL, mixed lineage leukemia; PRC, polycomb repressive complex; PRE, polycomb response element; TRX, trithorax.

\footnotetext{
*Address correspondence to: Vani Brahmachari. ACBR, University of Delhi, Delhi-110007, India. Tel: 27666272. E-mail: vani.brahmachari@gmail.com

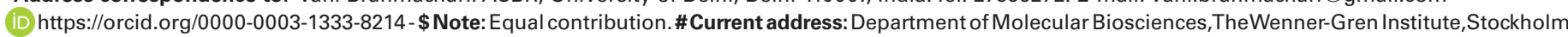

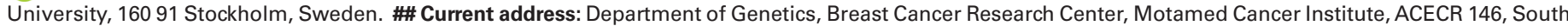
Gandhi Ave, Vanak Sq, Tehran, Iran.
}

Supplementary Material (one table) for this paper is available at: https://doi.org/10.1387/ijdb.190285vb

Submitted: 30 August, 2019; Accepted: 28 October, 2019.

ISSN: Online 1696-3547, Print 0214-6282

(c) 2020 UPV/EHU Press

Printed in Spain 


\section{DNA methylation}

The modification of DNA leading to hyper- or hypomethylation of $\mathrm{CpG}$ islands in the promoter regions is an important epigenetic mechanism for transcription regulation (Deaton and Bird, 2011). DNA methyltransferases catalyze the transfer of methyl group from S-adenosyl methionine (SAM) to DNA. The DNA methyltransferases are categorized on the basis of the site of methylation (m6A, m4C and m5C). 6-methyl-adenine and 4-methylcytosine were initially identified in only prokaryotes (Ratel et al., 2006). However, there are recent reports of their presence in eukaryotes (Heyn and Esteller, 2015; Xiao et al., 2018).

The methylation of cytosine residues $(5 \mathrm{mC})$ at the $\mathrm{CpG}$ dinucleotide, is generally associated with the regulatory regions and mediates the repression of the associated genes, whereas $5 \mathrm{mC}$ within the gene body leads to increased expression in mammals (Hellman A and Chess A, 2007; Aran et al., 2010).

DNA methylation is reported in all higher eukaryotes, though its presence in Drosophila is disputed. The presence of very low levels of $5 \mathrm{mC}$ in Drosophila genome is reported (Gowher et al., 2000; Capuano et al., 2014). Deshmukh et al., (2018) reported a varying $5 \mathrm{mC}$ levels during the life cycle of Drosophila and also compared the level of $5 \mathrm{mC}$ in different subgenus of Drosophila. They detected high $5 \mathrm{mC}$ levels in embryo and larva but a drastic reduction in pupae. The reduced level is maintained throughout the adult stages in both males and females. Furthermore, in male flies, higher $5 \mathrm{mC}$ levels were found in head tissue as compared to the whole body. A marked difference in the $5 \mathrm{mC}$ level was observed between 12 species of the subgenera of Drosophila and Sophomora with Drosophila melanogaster showing the lowest $5 \mathrm{mC}$ levels and Drosophila persimilis showing the highest (Deshmukh et al., 2018). The same group reported the detection of active DNA methyltransferase in adult flies (Panikar et al., 2015).

\section{DNA methyltransferases}

The methylation of cytosine at the $5^{\text {th }}$ position $(\mathrm{m} 5 \mathrm{C})$ which is common in eukaryotes, is brought about by DNAmethyltransferases (DNMTs). There are three mammalian DNA methyltransferases DNMT1, DNMT3A and DNMT3B with different activities (Table 2).

DNMT3 is responsible for de novo DNA methylation of cytosine residues during gametogenesis and early development. Unlike multiple DNA methyltransferases in mammals, Drosophila has only DNMT2, however the DNA methylation in the fly was found to be independent of DNMT2 (Takayama et al., 2014). The lack of most DNMT genes in Drosophila was effectively utilized to
TABLE 1

\section{DISEASES IMPLICATED IN EPIGENETIC DYSFUNCTION}

\begin{tabular}{|c|c|c|c|}
\hline $\begin{array}{l}\text { Drosophila } \\
\text { homologue }\end{array}$ & $\begin{array}{l}\text { Human homo- } \\
\text { logue }\end{array}$ & Associated disease & Reference \\
\hline$E(z)$ & $\mathrm{EZH} 2$ & Weaver syndrome & Gibson et al., 2012 \\
\hline Esc & EED & $\begin{array}{l}\text { Hodgkin's Lymphoma, Acute Promyelo- } \\
\text { cytic Leukemia }\end{array}$ & Dukers et al., 2004 \\
\hline Pho & YY1 & Hailey-hailey disease, brain glioma & Kawada et al., 2005 \\
\hline Pc & CBX2 & Gonadal dysgenesis & Norling et al., 2013 \\
\hline Brm & SMARCA2 & Nicolaides Baraitser syndrome & Van Houdt et al., 2012 \\
\hline Osa & ARID1A/BAF250 & Coffin-siris syndrome & $\begin{array}{l}\text { Kosho et al., } 2014 \\
\mathrm{a} \text { and b }\end{array}$ \\
\hline Trx & MLL & Acute leukemias & Munoz et al., 2003 \\
\hline Kis & CHD7 & Charge syndrome, Kallmann syndrome & Kim et al., 2008 \\
\hline
\end{tabular}

understand the consequence of ectopic expression of DNMT3L and its interaction with Histone $\mathrm{H} 3$, lacking methylation at $4^{\text {th }}$ lysine residue (H3K4) (Basu et al., 2016). DNMT3L connects DNA methylation with histone methylation. It drives DNA methylation by recruiting DNMT3A and $3 B$ upon encountering histone $\mathrm{H} 3$ lacking methylation $\mathrm{H} 3 \mathrm{~K} 4$, which is a signature for active transcription (Ooi et al., 2007). To dissect the functional significance of interaction of DNMT3L exclusively with $\mathrm{H} 3$, mammalian DNMT3L was ectopically expressed in Drosophila melanogaster. The ectopic expression of DNMT3L in flies results in the reduction of active histone marks including H3K4me1, 2 and 3 and $\mathrm{H} 3 \mathrm{~K} 36 \mathrm{me} 3$. This is correlated with the induction of tumors, though no altered DNA methylation is detected (Basu et al., 2016). Furthermore, the epimutation leading to nuclear reprogramming is trans-generationally inherited; the phenotypic effect increasing progressively through generations is totally dependent upon the presence of ectopically expressed DNMT3L (Basu et al., 2016). The flies resume normal development once the ectopic expression of DNMT3L is terminated, suggesting the role of DNMT3L as a reader of histone methylation status in cells through the developmental stages (Gokul et al., 2007, Basu et al., 2016).

\section{Proteins interacting with methylated DNA}

The readers of methylated $\mathrm{CpGs}$ are proteins belonging to the methyl-binding domain (MBD) family, zinc finger proteins and UHRF (Ubiquitin-like with PHD and Ring finger) proteins. The MBD family proteins directly bind to the methylated DNA and recruit various repressor complexes: MBD1 that interacts with SETDB1 (SET domain bifurcated histone lysine methyltransferase 1) and of MBD2 interacting with NuRD corepressor complex (Nan et

TABLE 2

\section{DNA METHYLTRANSFERASES (DNMTS) AND ASSOCIATED FUNCTIONS}

\begin{tabular}{|c|c|c|c|}
\hline DNMTs & Function & Associated anomalies & Reference \\
\hline DNMT1 & Maintenance of DNA methylation & $\begin{array}{l}\text { Neuropathy, Cerebellar ataxia, Deafness, Gastric cancer, Hepatocellular carcinoma, Pancreatic cancer, } \\
\text { Colon cancer }\end{array}$ & $\begin{array}{l}\text { Robert et al., 2003; Reviewed in Subra- } \\
\text { maniam et al., } 2014\end{array}$ \\
\hline DNMT2 & DNA and RNA methylation & Hepatocellular carcinoma, Colorectal carcinoma & Reviewed in Subramaniam et al., 2014 \\
\hline DNMT3A & De novo methylation of DNA & $\begin{array}{l}\text { Acute myeloid leukemia, Tatton-Brown-syndrome, Rahman syndrome, Gastric cancer, Hepatocellular } \\
\text { carcinoma, Pancreatic cancer }\end{array}$ & $\begin{array}{l}\text { Okano et al., 1999; Reviewed in Subra- } \\
\text { maniam et al., 2014; Kaneda et al., } 2004\end{array}$ \\
\hline DNMT3B & De novo methylation of DNA & $\begin{array}{l}\text { Facioscapulohumeral Muscular Dystrophy 2, Immunodeficiency-centromeric instability-facial (ICF) anom- } \\
\text { alies syndrome 1, Gastric cancer, Breast cancer, Colon cancer }\end{array}$ & $\begin{array}{l}\text { Okano et al., 1999; Reviewed in Subra- } \\
\text { maniam et al., } 2014\end{array}$ \\
\hline DNMT3L & $\begin{array}{l}\text { Regulates the activity of DNMT3a } \\
\text { and DNMT3b }\end{array}$ & Taylor's syndrome, Cervical cancer, Embryonal carcinoma & $\begin{array}{l}\text { Gowher et al., 2005; Reviewed in Subra- } \\
\text { maniam et al., } 2014\end{array}$ \\
\hline
\end{tabular}


al., 1993). MeCP2 (Methyl-CpG binding protein), another MBD containing protein, associates with the complex consisting of SIN3 transcription factor (SIN3A) and histone deacetylases, leading to inactive chromatin state (Laherty et al., 1997). The Zinc finger protein Kaiso and ZBTB4 (Zinc finger and BTB domain containing protein 4) binds to methylated DNA leading to transcriptional repression. Unlike these two proteins, the UHRF proteins play a key role in DNMT1 mediated maintenance of DNA methylation. UHRF has a unique SET and Ring finger domain that recognizes hemi-methylated DNA and recruits DNMT1 to the hemi-methylated DNA during replication (Hashimoto et al., 2008; 2009). ESCs lacking DNMT3A and $3 \mathrm{~B}$ are completely devoid of DNA methylation which does not affect pluripotency, but inhibits differentiation (Jackson et al., 2004). On initiation of differentiation of the ESCs, the genes associated with pluripotency including Nanog and Oct4 are silenced by promoter hyper-methylation. DNMT1, 3A or 3B null mice die early either as embryos or soon after birth owing to impaired methylation pattern (Li et al., 1992; Okano et al., 1999). These three enzymes have high expression in the brain tissue and their depletion results in various neuronal anomalies. Aconditional depletion of DNMT1 in the mouse embryonic neuronal precursor cells causes hypomethylation in neuronal tissues leading to impaired activity (Fan et al., 2001).

DNA methylation is indispensable for dosage compensation of $\mathrm{X}$ linked genes in mammalian females and differs significantly between the active and the inactive $\mathrm{X}$ chromosomes (Cotton et al., 2015). DNA methylation is an important player in the parental specific gene expression or genomic imprinting where one of the alleles is inactive. Thus, DNA methylation has an important role in successful completion of development not only through imprinting but also through regulating other processes during development.

\section{Dynamic changes in DNA methylome during development}

One of the attractive features of DNA methylation as an epigenetic mark is the replication associated reversibility of the process, brought about by pausing de-novo methylation. More recently, the enzymatic demethylation was discovered where the TET protein (Ten Eleven Translocation protein) oxidizes $5 \mathrm{mC}$, and unmodified cytosine is replaced through DNA repair pathway (Tahiliani et al., 2009). The three mammalian Tet proteins (Tet 1, 2 and 3 ) catalyze a step- wise oxidation of $5 \mathrm{mC}$. The cys-rich domain and the DSHB domain of Tet proteins are responsible for the methylcytosine dioxygenase activity. The CXXC domain of Tet1 and Tet3 binds to $\mathrm{CpG}$ islands. During the process of oxidation of $5 \mathrm{mC}, 5$ hydroxymethylcytosine $(5 \mathrm{hmC})$ is formed as an intermediate which is also established as an epigenetic mark. A neonatal lethal phenotype is observed in mouse in the absence of the $5 \mathrm{hmC}$ mark and Tet3 enzyme. Thus, $5 \mathrm{mC} / 5 \mathrm{hmC}$ switch is essential in regulating the organismal development (Gu et al., 2011). $5 \mathrm{mC}$ is associated with closed chromatin (Chouliaras et al., 2012) whereas, the $5 \mathrm{hmC}$ is preferentially found in euchromatic regions and is enriched at enhancers, promoters, and the gene body, suggesting its role in transcription activation in mouse (Song et al., 2011; Nestor et al., 2012). In human and mouse, the ESC s have higher levels of $5 \mathrm{hmC}$ than the differentiating cells. The reduced $5 \mathrm{hmC}$ levels, correlate with the modulation in gene expression during transition from pluripotency to differentiation (Ficz et al., 2011; Ko et al., 2011). Similarly, in the differentiating somatic cells, change in the levels of $5 \mathrm{hmC}$ is observed during lineage commitment (Bocker et al., 2012). In mice, the level of $5 \mathrm{hmC}$ is abundant in the brain tissues and is found to be essential for the spatial and temporal control of neural differentiation (Orr et al., 2012; Song et al., 2011). MeCP2, which is also abundant in the brain, reads $5 \mathrm{hmC}$ as it does $5 \mathrm{mC}$. One of the mutations in the MeCP2 gene, implicated in Rett syndrome, a neurodevelopmental disorder, disrupts the binding of MeCP2 with $5 \mathrm{hmC}$, but not with $5 \mathrm{mC}$, underscoring the significance of $5 \mathrm{hmC}$ and the DNAdemethylation machinery in development(Mellen etal., 2012).

During development, the methylation pattern is reprogrammed in germ cell precursors. Post-fertilization, the gametic methylation (except those of imprinted loci) is erased followed by re-initiation of the tissue specific methylation
Fig. 1. Function of cellular memory modules. The core complex for activation, the trithorax complex (A) and the repressive polycomb complex (B) are shown. The initial signals are transient in nature, their loss may revert the transcriptional state of the gene. The cellular memory modules maintain the activated or the silenced state by changing the chromatin environment.

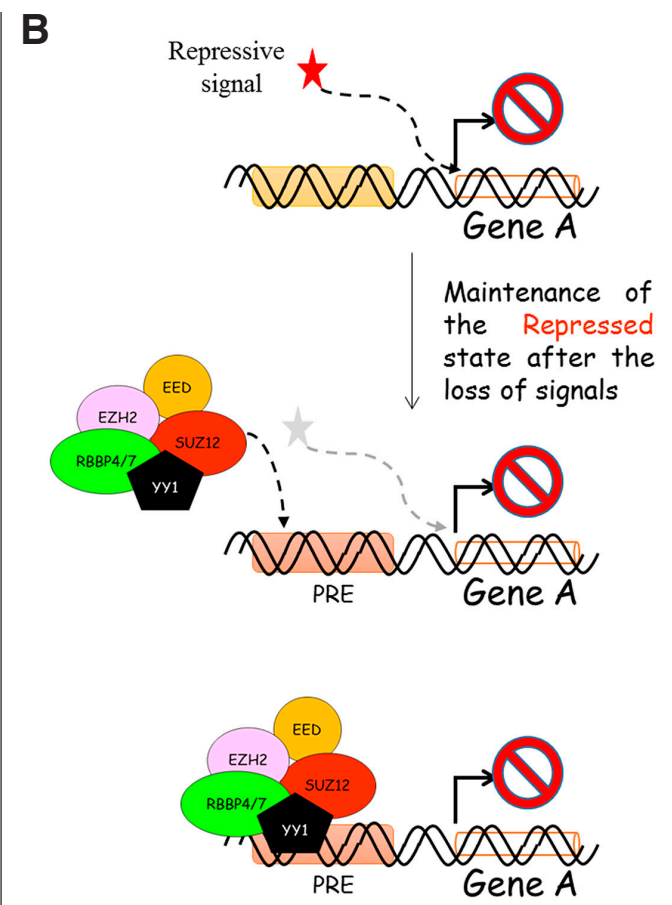


pattern in the implanted embryos. Earlier studies utilized the $c$-fos gene as a probe to investigate the dynamic changes in methylation pattern during development (Uehara et al., 1989). It was found that the $c$-fosgene is devoid of DNA methylation at the 5'end that includes part of the regulatory region and the $1^{\text {st }}$ exon. However, the 3 'end of the gene displays tissue specific as well as age specific dynamicity in DNA methylation (Uehara et al., 1989). Raman and his group furthered these studies to understand the changes in methylation pattern in the coding region of $c$-fos locus in mouse liver during development. Their study revealed that the perinatal methylation in the $c$-fos locus is directional, initiated at the 3'end of the gene, it proceeds gradually towards 5' end leading to the methylation of the various CpG sites in a stepwise manner through development and is influenced by the CpG spacing in the gene (Chandrashekhar and Raman, 1997; Sachan and Raman, 2008). The regulation of $c$-fos is very important, as its mis-regulation in mouse liver leads to premalignant transformations (Bakiri et al., 2017).

In fragile $X$ syndrome, disease manifestation is strongly associated with DNA methylation. The major molecular etiology of this syndrome is the expansion of (CGG)n triplet repeat in the 5'untranslated region of FMR1 gene followed by methylation of the upstream regulatory sequence leading to transcription inhibition (Kraan et al., 2019). Therefore, repeat expansion without DNA methylation would not lead to fragile $X$ syndrome, while DNA methylation without (CGG)n expansion can lead to the disease. Using transgenic mice, we have shown that DNA methylation occurs with or without repeat expansion (Alam et al.,2010). Therefore, DNA methylation and repeat expansion are independent events. These transgenic mice contained a part of the 5ÚTR of human FMR1 gene with (CGG)26 which showed repeat expansion at a high frequency in several transgenic lines (Baskaran et al.,2002). There are reports of lack of methylation in two clinically normal brothers with (CGG) $\mathrm{n}$ expansion (Smeets et al., 1995). Therefore, evaluation of DNA methylation status at FMR1 locus in unclassified mental retardation patients is necessary.

In addition to cytosine methylation, the role of N6-methyl deoxy adenosine is being increasingly explored. The data comes from $C$. elegans and Drosophila. In Drosophila, $6 \mathrm{~mA}$ is associated with actively transcribed genes. Its level is controlled by $6 \mathrm{~mA}$ demethylase (DMAD) (Zhang et al., 2015). By knock-down of 6mA demethylase, they showed that $6 \mathrm{~mA}$ levels are controlled by active demethylation at later stages of embryonic development which is important for the completion of normal development and tissue homeostasis. Recent report confirms the presence of $6 \mathrm{~mA}$ in the human genome and its distribution is correlated with active genes (Xiao et al., 2018). In fungi, there is evidence to show an inverse correlation between genomic distribution of $5 \mathrm{mC}$ and $6 \mathrm{~mA}$ (Mondo et al., 2017).

A study by Greer et al. (2015) identified 6mA methylation along with its DNA methyltransferase and demethylase in C. elegans and demonstrated its role in trans-generational epigenetic inheritance. They demonstrated a cross talk between active histone methylation and $6 \mathrm{~mA}$ using fertility mutants of $C$. elegans.

DNA methylation does not regulate the chromatin function in isolation. The cross-talk between DNA methylation and histone modification is well known and the two processes cooperate closely (Rose and Klose, 2014). The indirect interaction of methylated DNA with HDACs throws light on the mechanisms that link DNA methylation with histone modification. The recruitment of SETDB1, to the methylated DNA, indicates the cross-talk between DNA methyla- tion and histone modification in the formation of heterochromatin (Reviewed in Du et al., 2015). MeCP2 is associated with histone methyltransferase (Suv39h1/2), that modifies histone $\mathrm{H} 3$ at lysine 9 (H3K9me) (Fuks etal., 2003). Thus, the chromatin modifiers, writers involved in modifying the histones, readers that respond to histone modifications and the erasers that remove the histone modifications are essential for the regulation of open/active or closed/repressed chromatin architecture.

\section{Differential bookmarking of histones at transcriptionally active, repressed and poised loci}

The post-translational modification of histones $\mathrm{H} 2 \mathrm{~A}, \mathrm{H} 2 \mathrm{~B}, \mathrm{H} 3$ and $\mathrm{H} 4$ adds an important dimension to epigenetic control of gene expression. The male and female gametes differ in the patterns of epigenetic marks. Soon after fertilization, the protamines in sperm chromatin are replaced with histones and the gametic epigenetic pattern is remodeled to allow the transition from maternal to zygotic control of genome activation (ZGA) which is followed by the expression of developmental genes (Shao et al., 2008). The reprogramming events during ZGA is controlled by the maternally derived factors including histone modifying enzymes that guide the chromatin environment to ensure the proper cell fate maintenance and differentiation through the developmental time line (Bultman et al., 2006). Acetylation of histones is associated with the activation whereas the histone methylation guides either activation or repression of transcription depending upon the site of modification. The repressive state is marked by $\mathrm{H} 3 \mathrm{~K} 27$ me3 whereas $\mathrm{H} 3 \mathrm{~K} 4 \mathrm{me} 1 / 2 / 3$ and $\mathrm{H} 3 \mathrm{~K} 27 \mathrm{ac}$ mark active state of gene expression. Methylation of lysine residues (mono-, di-, and tri-methylations abbreviated as me1, me2 and me3 respectively) is regulated by the methyltransferases that contain the characteristic SET domain (130-140 amino acid domain initially identified in Drosophila Su(var)3-9, Enhancer-ofzeste and Trithorax). S-adenosyl-L-methionine (SAM) acts as the cofactor in this reaction. However, DOT1L (DOT1-like) does not contain SET domain but has methyltransferase activity, methylating histone H3K79 (Feng et al., 2002). It is conserved from yeast to humans and is correlated with negative regulation of transcription in yeast, while in the human genome regions of high elongation rate are associated with H3K79 methylation (Vlaming and Leeuwen, 2016).

There are other well-known histone modifications such as ubiquitinylation, phorphorylation, biotinylation, ribosylation and citrullination. A number of amino acid residues on the N-terminal tails of histone proteins are modified. Some of the commonly modified residues are lysine (methylated/acetylated), arginine (methylated), serine (phosphorylated), threonine (phosphorylated), tyrosine (phosphorylated). The nature of modification and the residue modified dictates the state of transcription; either activation or silencing.

\section{Repressed chromatin state is maintained by Polycomb group of proteins}

The Polycomb group (PcG) proteins were discovered as regulators of homeotic genes in Drosophila melanogaster (Lewis, 1978; Struhl, 1981). The PcG proteins are responsible for the maintenance of closed chromatin architecture and are mainly grouped into two main complexes: PRC1 and PRC2 (Table S1 and Fig.2).

The PcG proteins are widely expressed in the Drosophila embryo and their function is well defined both spatially and temporally 
A

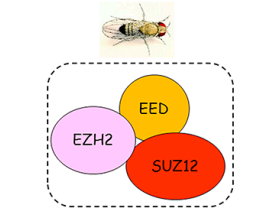

Core protein members of the Drosophila PRC2 complex
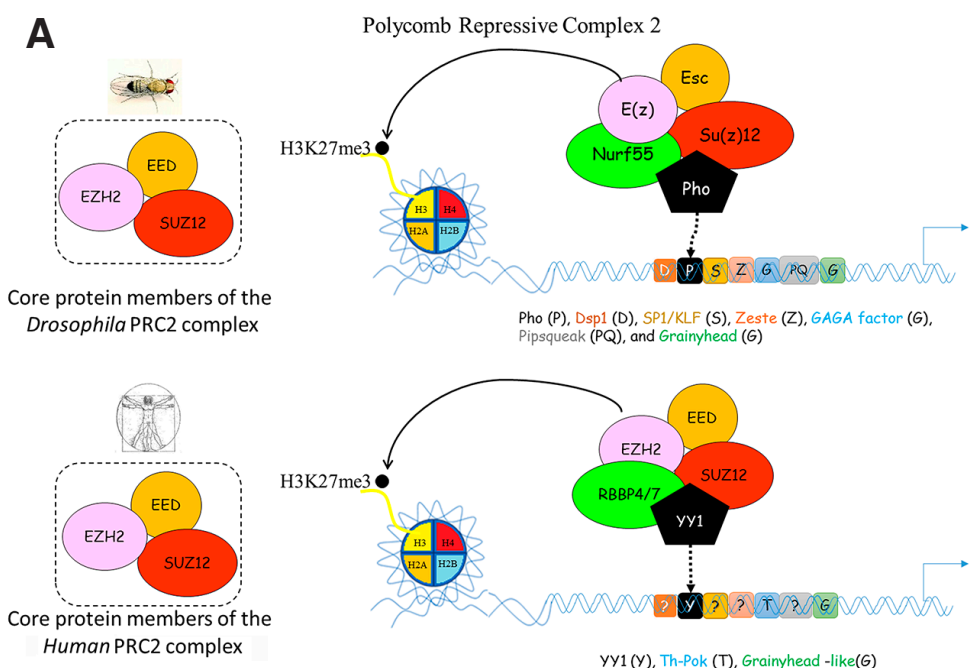

yy1 (y), Th-Pok (T), Grainyhead -like(G)

B
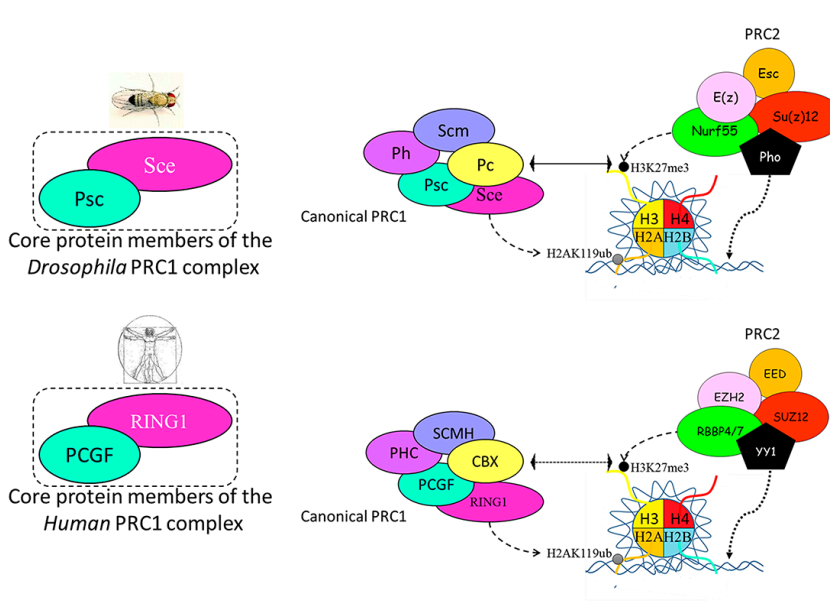

Polycomb Repressive Complex 1

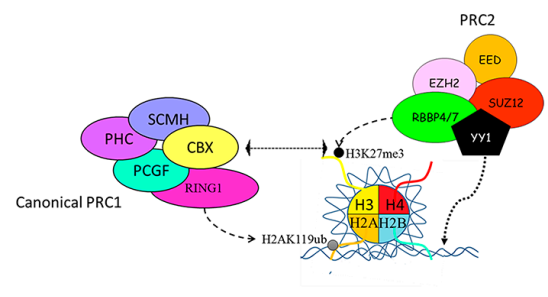

Fig. 2. Conservation of polycomb machinery between Drosophila and Humans. The PRC2 complex is recruited to the PRE with the help of transcriptions factors (Pho, Dsp1, SP1/KLF, Zeste, Trl/GAGA factor, Pipsqueak and Grainyhead in Drosophila and YY1, Grainyhead and Th-Pok in Humans). PRC2 complex brings about H3K27me3 via the SET domain in E(z) (EZH2 in human). The H3K27me3 mark is identified by the PRC1 complex and the RING1A/B protein from the same complex catalyze the H2A119Ub. These two epigenetic marks are repressive in nature and lead to chromatin compaction.

(Mahmoudi and Verrijzer, 2001). The repression of homeotic genes at the early stages of development is under the control of the segmentation genes that act as negative regulators. It is only after the blastoderm stage that PcG-mediated repression of homeotic genes takes place (Struhl and Akam, 1985). This repression is mitotically stable and the misexpression of PcG proteins in Drosophila leads to homeotic transformations.

The PRC1 complex is mainly responsible for the ubiquitination of H2AK119, mediated by RING1A/B protein (Fig. 2; Wang et al., 2004). Along with the canonical PRC1 (cPRC1) complex (Table $\mathrm{S} 1$ ), several non-canonical PRC1 (ncPRC1) complexes exist in mammals, one of the ncPRC1 contains RYBP (Ring1 and YY1 binding protein) instead of CBX (Chromobox; binds to H3K27me3) of cPRC1 (Gao et al., 2012). Unlike the ubiquitination activity of PRC1, another PcG complex, Polycomb repressive deubiquitinase complex (PR: DUB) has H2A specific deubiquitinase activity, suggesting a tight control of dynamic deposition and removal of H2AK119ub mark is required for the PcG mediated transcriptional silencing (Table S1, Scheuermann et al., 2010).

The EZH2 protein in the PRC2 complex contains the SET domain which brings about $\mathrm{H} 3 \mathrm{~K} 27$ methylation (H3K27me3). EZH1/2 alone has very low-level of histone methyltransferase activity which increases to several fold when it is coupled with other core components of the PRC2 complex (Table S1) (Cao et al., 2002; Cao and Zhang, 2004; Reviewed in Schuettengruber et al., 2017).

The recruitment of these proteins to chromatin requires cisacting DNA elements, Polycomb Responsive Elements (PREs) (discussed later in this review) and several trans-acting factors that include sequence specific DNA binding proteins and transcription factors. The PRC1 and 2 complexes show inter-dependence in certain cases, where $\mathrm{CBX}$ proteins recruit PRC1 complex to the H3K27me3 sites, while PRC2 recruitment to the PRC1 induced H2AK119ub marks is aided by AEBP2 and JARID2, both being DNA-binding transcription repressors (Wang et al., 2004; Cooper et al., 2014). However, the two complexes are also known to be recruited independently (Kahn et al., 2016). RYBP containing
PRC1 complexes are recruited to target loci even in the PRC2deficient mESCs, bringing about Polycomb silencing (Tavares et al., 2012). In Drosophila, stalled promoter of some of the coding and non-coding genes recruit PRC1 but not the PRC2 complex (Enderle et al., 2011).

The absence of PRC2 components, SUZ12, EZH2, EED or $P R C 1$ component RING1A/B, leads to embryonic lethality in mouse whereas mutants for CBX2 or CBX4 show postnatal lethality (Baumann and Fuente, 2011). PcG proteins are abundantly present in ESCs and regulate pluripotency and also direct their differentiation. The CBX protein, CBX7 is abundant in pluripotent stem cells whereas the differentiating cells are enriched with CBX2 and 4. A failure to switch the CBX7 proteins with CBX2 or 4 leads to overproliferation in hematopoietic stem cells culminating in leukemic condition (Klauke et al., 2013). These studies suggest that different PRC1 complexes with diverse CBX proteins are targeted to distinct sites to regulate stem cell maintenance and differentiation.

Along with the differential deposition of $\mathrm{H} 3 \mathrm{~K} 27 \mathrm{me} 3$, which is guided by the recruiters of polycomb complex, the reprogramming event utilizes specific demethylases namely the UTX/KDM6A, UTY/KDM6C and JMJD3/KDM6B. The other demethylases such as the PHF subfamily proteins containing JmjC domain, PHF8 and KIAA1718/KDM7A (which additionally contains PHD) are specific for H3K27me2 (Agger et al., 2007). KDM7A identifies the H3K27me2 on the nucleosomes containing the H3K4me3 mark as well (Reviewed in Hyun et al., 2017). Thus, the demethylases help in the modulation of histone marks across the genome, affecting the transcription repertoire to regulate stem cell differentiation and cell fate specification in mouse.

The depletion of polycomb group proteins inhibits the process of dedifferentiation whereas the down regulation of their respective demethylases promotes mesenchymal to epithelial transition (MET) leading to the generation of induced pluripotent stem cells (iPSCs) (Onder et al., 2012 and Mansour et al., 2012). Shravanti Rampalli and her group detailed the role of Ezh2 in MET in the mouse fibroblast cells. TGF $\beta$ pathway is a major inducer of Epithe- 
A

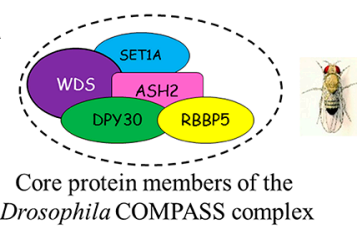

Drosophila COMPASS complex

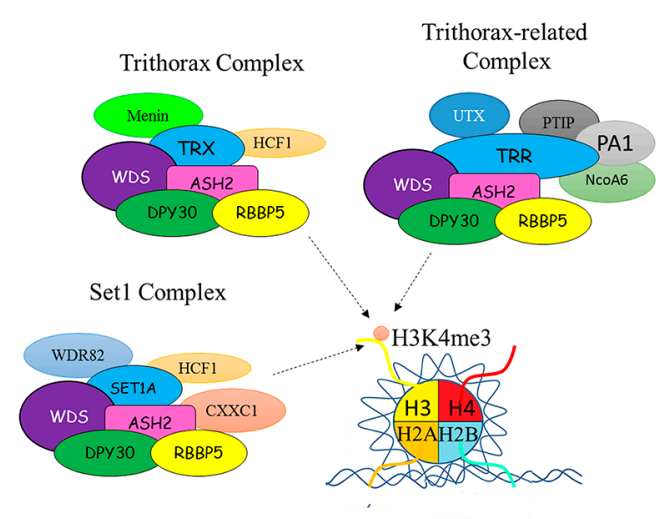

B

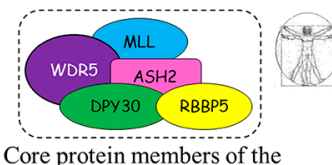

Core protein members of the Human COMPASS complex

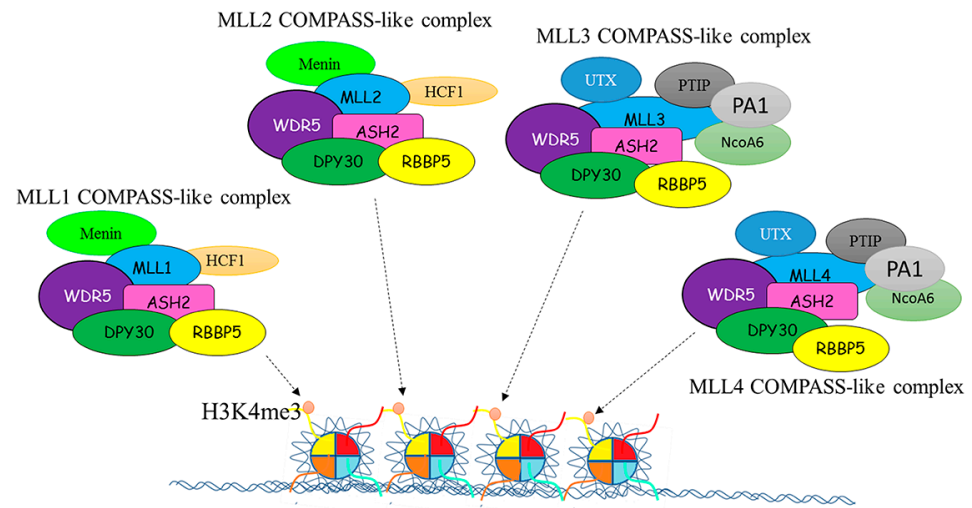

Fig. 3. Conservation of trithorax machinery between Drosophila and Humans. The trithorax complexes in Drosophila are divided on the basis of the SET domain containing proteins [SET1A, TRX (Trithorax) and TRR (Trithorax-related)], that bring about H3K4me3, as well as the accessory proteins (HCF1, PA1, NCOA6, PTIP, CXXC1). Similar classification is made for the Human COMPASS complexes on the basis of enzyme [MLL1, 2, 3 and 4] and accessory proteins. The H3K4me3 is an active mark that brings about transcriptional activation.

lial to Mesenchymal Transition (EMT). Over-expression of Ezh2 reduced the expression of TGF $\beta$ receptor whereas down regulation of Ezh2 enhanced the expression. In a cascade of events, the down regulation of Ezh2 activates TGF $\beta$ pathway and subsequently activates the mesenchymal transcription factor, Snail. This suggests that Ezh2 regulates EMT by repressing the TGF $\beta$ pathway epigenetically. Using H3K27me3 inhibitor, GSK-126, it was confirmed that Ezh2 mediated H3K27me3 activity down regulates the TGF $\beta$ signaling and promotes MET during iPSC generation (Rao et al., 2015). The effects of epigenetic modifiers and their respective modifications upon various developmental pathways have been studied in detail and reviewed elsewhere (Liedtke and Cleary, 2009; Mishra et. al., 2012; Zhou et al., 2018).

\section{Trithorax group proteins and transcriptional activation}

The maintenance of active gene expression is a complex process requiring a variety of factors. Thus, Trithorax Group (TrxG) proteins include functionally diverse proteins having DNA binding, histone modifying and chromatin remodeling activity (Fig. 3). These complexes bring about the maintenance of the activated state of the target genes (Kingston and Tamkun, 2014).

Among the Trithorax group of proteins, the multimeric-SET1 or COMPASS complex, is responsible for $\mathrm{H} 3 \mathrm{~K} 4$ methylation (mono, di and tri methylation; Table S1 and Fig. 3). In mammals, there are 6 SET1-like complexes; SET1A, 1B; MLL1, 2, 3 and MLL4, whereas, in Drosophila, 3 complexes are known, Set1, Trx and TRR (Table S1; Shilatifard et al., 2008; Ardehali et al., 2011). Each of these Set1 homologs interact with a core complex abbreviated as WRAD consisting of four proteins (WDR5, RbBP5, ASH2L and DPY30) along with several accessory proteins which provide stability and specificity to the complex and enhance the methyltransferase activity of SET1 proteins (Table S1; Takahashi et al., 2011; Ernst and Vakoc, 2012, Reviewed in Schuettengruber et al., 2017). The different SET1 complexes interact with diverse transcription factors and catalyze H3K4 methylation at distinct loci. SET1A/B leads to trimethylation at H3K4, mainly at promoters of the active genes while MLL1 deposits H3K4me3 at a small subset of genes including Hox genes (Guenther et al., 2005) and H3K4me2 at PREs (Rickels et al., 2016). MLL2 directs H3K4me2 at the bivalent promoters in ESCs (Denissov et al., 2014) and UTX in MLL3/4 complexes can remove the repressive H3K27me3 marks, followed by MLL3/4 mediated deposition of H3K4me1 at enhancers (Agger et al., 2007; Shinsky et al., 2015). The H3K4me3 methylation also mark the imprinted loci by differential distribution, depending upon parental origin. These marks were found to be associated with the transcriptionally active loci (Zhang et al., 2016).

The recruitment of Trx complexes to the chromatin is also mediated by some of the transcription factors involved in recruiting PCG proteins. In addition, the active transcriptional status of chromatin itself promotes the recruitment of Ash1 (having SET and Bromodomain and H3K36 methyltransferase activity) and $\mathrm{Brm}$ (helicase and Bromodomain containing protein) (Dejardin and Cavalli, 2004). CXXC domain in MLL1/2 and CFP1 proteins can recruit the Trx complex to CpG islands (Ayton et al., 2004; Thomson et al., 2010). WDR5 (WD40 repeat containing protein) can bind to H3K4 irrespective of its methylation status and can recruit TrxG proteins. H3K4me3 and H3K36me3 marks deposited by Trx complex inhibit the PRC2 activity on the associated histones (Yuan et al., 2011; Schmitges et al., 2011). Moreover, acetylation activity of $\mathrm{CBP}$ in conjunction with $\mathrm{Trx}$ at $\mathrm{H} 3 \mathrm{~K} 27$ also prevents PRC2 mediated methylation (Tie et al., 2009).

In Drosophila, the TrxG proteins act antagonistically to the polycomb mediated repressive activity and regulate the expression of many developmental genes including the Hox genes (Kennison 
and Tamkun, 1988). Drosophila embryos with Ash1 and Trx mutations exhibit mis-expression of Hox genes that is reversed when the PcG mutations were brought in combination (Klymenko and Müller, 2004).

TrxG proteins regulate pluripotency and differentiation in ESCs. WDR5 in combination with Oct4 regulates H3K4me3 deposition on genes involved in stem cell self-renewal and somatic cell reprogramming (Ang et al., 2011). Similarly, ASH2L is known to regulate the stem cell pluripotency (Wan et al., 2013) whereas DPY30 (protein homodimerization activity) regulates ESC differentiation (Jiang et al., 2011). MLL deficient mouse die at embryonic stage, however the hypomorphs exhibit homeotic transformation of axial skeleton and anomalies in haematopoiesis (Yu et al., 1995). BRM/BRG1 regulates transcription of genes involved in early embryonic development by regulating zygotic control of gene activation along with proliferation and differentiation of neurons and hematocytes (Bultman et al., 2000; 2005; 2006).

These histone marks are read by various proteins that trigger the downstream process of gene regulation. The H3K4me2 and H3K4me3 are recognized by CHD1 (Chromodomain Helicase DNA Binding Protein 1) which is also important for maintaining open chromatin structure in the pluripotent stem cells (Sims et al., 2005). BPTF (bromodomain PHD finger transcription factor), a subunit of the NURF (Nucleosome Remodeling Factor) complex recognizes H3K4me3 via its $\mathrm{PHD}$ domain. Both $\mathrm{CHD} 1$ and NURF remodel nucleosome in ATP dependent manner. Several other histone modifying enzymes like SAGA (Spt-Ada-Gcn5 acetyltransferase) complex recognize the H3K4 methylation and acetylate the nearby histones (Bian et al., 2011).

The dynamic transcriptional network controlling embryonic development requires extensive reprogramming of the histone methylation marks. Lysine specific demethylase 1 (LSD1/KDM1A) (Shi et al., 2004) and LSD2/KDM1B, demethylate H3K4me1 and H3K4me2 (Fang et al., 2013); jumonji AT rich interactive domain 1 (JARID1A/KDM5A), JARID1B/KDM5B, JARID1C/KDM5C, JARID1D/KDM5D specifically demethylate $\mathrm{H} 3 \mathrm{~K} 4 \mathrm{me} 2$ and $\mathrm{H} 3 \mathrm{~K} 4 \mathrm{me} 3$ whereas JmjC domain containing protein NO66/MAPJD can demethylate all the three states of methylation of H3K4. LSD1 is derived maternally in mouse embryos and is implicated in ZGA. Its absence in zygote leads to early lethality (Ancelin et al., 2016).

The genomic loci with activating or repressive marks demonstrate either "on" or "off" state of transcription, respectively. However, various sites are also marked by both activating as well as repressing marks and thus, create bivalent domains, leading to poised state of chromatin. In ESCs, the bivalent promoters maintain the pluripotency by repressing the genes involved in differentiation (Azuara et al., 2006; Bernstein et al., 2006). The rapid-fine tuning of various developmental genes are required specially when the transcriptional switches are highly dynamic and hence, in such a context, the bivalent domains provide greater flexibility in terms of timely activation of the downstream targets. The KDM6A and KDM6B demethylate H3K27me3 while KDM5A acts upon $\mathrm{H} 3 \mathrm{~K} 4 \mathrm{me} 3$ at bivalent promoters and regulates ESC maintenance or differentiation as required (Dahle et al., 2010; Schmitz et al., 2011; Dhar et al., 2016).

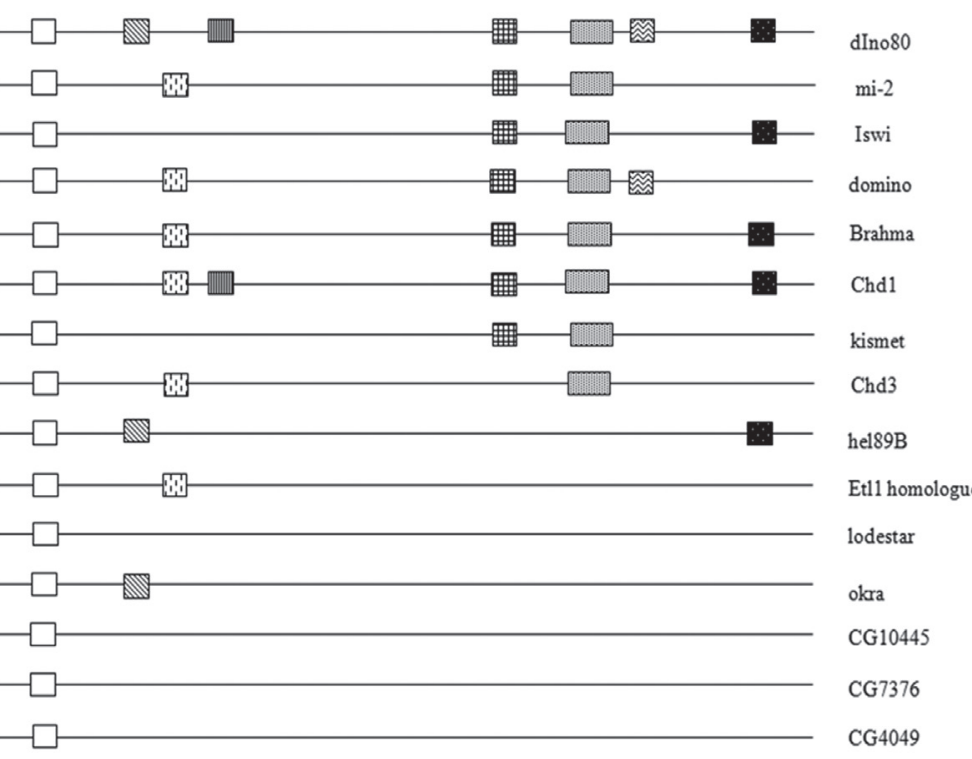

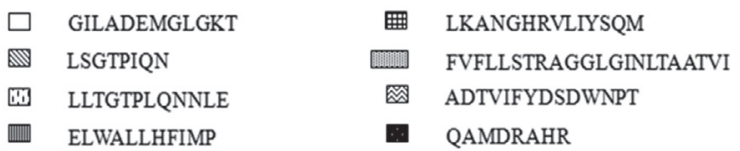

Fig. 4. The domain sharing pattern of different members of the SNF2 ATPase family. The common motif shared is the 14 mer peptide signature (unfilled box). The additional signature peptides shared between helicase domains of INO80 and members of SNF2 family previously characterised as PcG/TrxG proteins. (Jain et 2017).

\section{Histone acetylation leads to relaxed chromatin state}

Histone acetylation brought about by histone acetylases (HATs) relax the chromatin and thus, maintain an active chromatin state. On the basis of structural and functional similarity among the HATs, they have been classified into five subfamilies: the HAT1/KAT1; Gcn5/ PCAF or KAT2A/KAT2b; MYST; $p 300$ and CBP or KAT3B and KAT3A identified in metazoans only and a fifth fungal specific class Rtt109. Besides this, there are HATs that are less studied subfamilies. The Iysine moieties on histone tails; H2A (K5), H2B (K12, K15), H3 (K9, $\mathrm{K} 14, \mathrm{~K} 18, \mathrm{~K} 36, \mathrm{~K} 56)$, and $\mathrm{H} 4$ (K5, K8, K12, K16) are modified by HATs which ultimately leads to permissive chromatin state and facilitate the DNA binding proteins to interact with exposed DNA (reviewed in Marmorstein and Zhou, 2014). The histone acetylation is read by bromodomain containing chromatin remodelers that modulate the gene expression. HAT1 knockout mice are born with lung and skeletal defects, they lack acetylation on newly synthesized $\mathrm{H} 3$ and H4 and die soon after birth (Nagarajan et al., 2013). The acetylation on histone is reversed by histone deacetylase (HDAC) that couple with other repressor complexes to generate repressive chromatin state (reviewed in Marmorstein and Zhou, 2014).

\section{Repressive histone mark $\mathrm{H} 3 \mathrm{~K} 9 \mathrm{me} 3$ tags heterochromatin}

The tri-methylation at $\mathrm{H} 3 \mathrm{~K} 9$ is an established indicator of heterochromatin and is bound by Heterochromatin protein 1 (HP1) which recruits other epigenetic modifiers contributing to further chromatin 
compaction (Bannister et al., 2001). H3K9 methylation is brought about by SET domain containing H3K9 methyltransferases. SETDB1 leads to H3K9me1 modification at the pericentromeric region that acts as a substrate for $\mathrm{SUV} 39 \mathrm{H} 1 / 2$ which catalyzes H3K9 di- and trimethylation within constitutive heterochromatin domain. In euchromatic regions G9a and GLP (G9a-GLP) deposit H3K9me1 and me2, which has repressive role in gene expression (Brower-Toland et al., 2009). The gametic H3K9me3 and thus, heterochromatin domain is extensively reorganized after fertilization. In early mouse embryos, Chromatin assembly factor 1A (Chaf1a) leads to the enrichment of LTRs with H3K9me3 resulting in silencing (Wang et al., 2018). The levels of H3K9me3 is depleted around promoters after fertilization that allows proper zygotic gene activation (ZGA). During differentiation, H3K9me3 marks the genes to be repressed for the accurate cell fate determination (Becker et al., 2016). The genomic regions enriched with $\mathrm{H} 3 \mathrm{~K} 9 \mathrm{me} 3$ are distinct from those enriched with $\mathrm{H} 3 \mathrm{~K} 27 \mathrm{me} 3$, despite both being repressive in nature; $\mathrm{H} 3 \mathrm{~K} 9 \mathrm{me} 3$ is enriched in gene poor region whereas $\mathrm{H} 3 \mathrm{~K} 27 \mathrm{me} 3$ in gene rich region (Pauler et al., 2009). In contrast, there are reports of co-occurrence of the H3K9me3 and H3K27me3 at transposable elements mediated by Ezl1. Ezl1 (Enhancer of Zeste like protein) possess methylatranferase activity utilizing both $\mathrm{H} 3 \mathrm{~K} 9$ and H3K27 as substrate (Frapporti et. al., 2019).

\section{Mining novel epigenetic regulators from the genome sequence}

The identification of PcG and TrxG members in Drosophila has been mainly based on mutation screens and phenotypic assessment. In higher organisms including humans, the identification is homology based. The already known versatility of these complexes is currently much expanded both in terms of the protein partners in the complexes as well as the cis-elements where these complexes are recruited. As discussed in the earlier section, the involvement of the Polycomb and Trithorax Group (PcG/TrxG) of proteins in several disease processes, directly or as modifiers of the phenotype, has increased the relevance of identification of novel members of these global regulatory complexes.

The de novo identification and analysis for components of Polycomb and Trithorax complexes from the human genome will facilitate the identification of novel genes. However, homology based search may not be effective in defining the cellular function of the proteins and hence, the genes (Jain et al., 2017). In Drosophila, PcG and TrxG genes were identified based on the homeotic transformations seen in mutants of the genes (reviewed by Kassis et al., 2017). Subsequently, the genetic interactions were used to identify new members of polycomb, trithorax and the ETP proteins (Enhancer of Polycomb and Trithorax proteins), which interact with both the Polycomb and Trithorax complex. Therefore, the members of these groups are not identified by a common biochemical function.

In an attempt to address this issue, we searched for a signature sequence using the L-HOST software (Jain et al., 2017). L-HOST generates peptide library for the query proteins and detects identical peptides shared between two or more proteins. We used L-HOST to search for identical peptides shared between different Polycomb and Trithorax proteins and identified a 14mer peptide (NGILADEMGLGKTI), shared between Iswi and Brahma of which the 12 mer was highly conserved and found in several members of SNF2 family of chromatin remodeling proteins (Fig. 4; Jain et al., 2017). The search for this peptide in the non-redundant human proteome led to the identification of the hINO80 (Bakshi et al., 2004, Jain et al., 2017). In addition to the 14 mer peptide, many other peptide motifs are shared between chromatin remodelers of the Polycomb and Trithorax group (Jain et al., 2017). The analysis of the sequence and biochemical function of hINO80 mapping on chromosome 15 was carried out (Bakshi et al., 2004, 2006).

By multiple alignment of the INO80 protein from different organisms, a highly conserved sequence in all members of this family located near the N-terminus, upstream of the SNF2 helicase domain was detected (Fig. 5A; Bakshi et al., 2004.
Fig. 5. The conservation of the DBINO domain in INO80 homologues. The charged residues in the $\alpha$-helix (marked in colour) form the amphipathic helix in a helical wheel representation. (Bakshi et al., 2004).

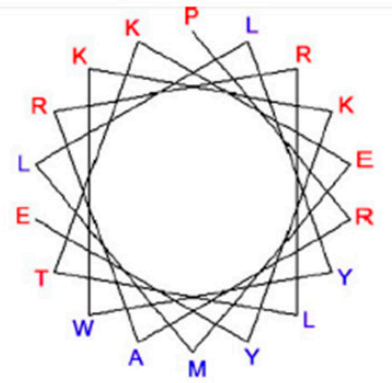




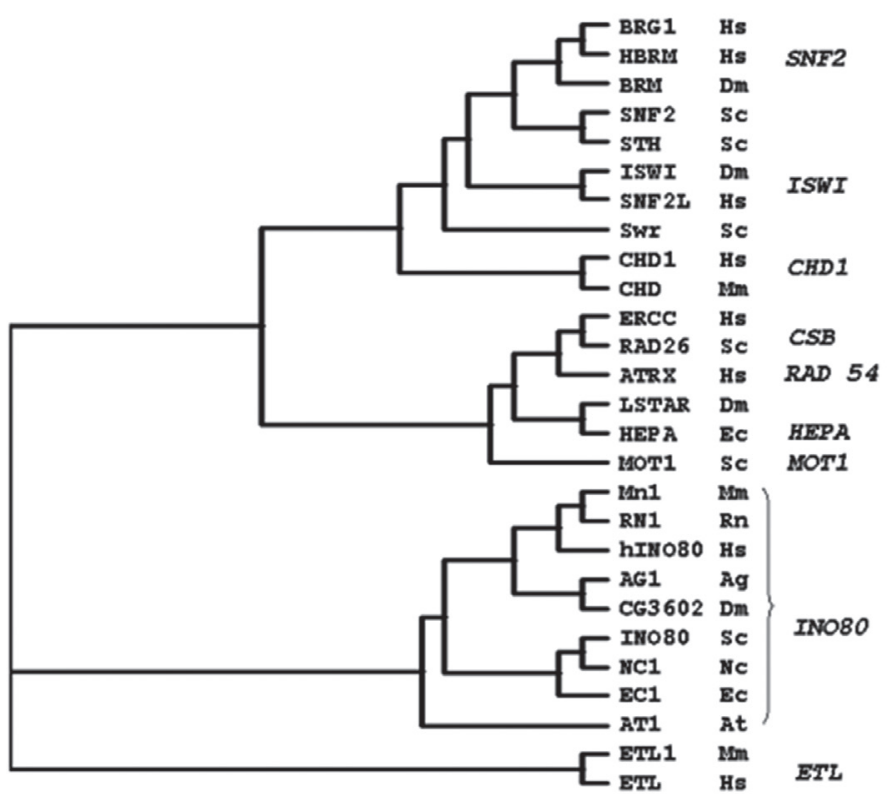

Fig. 6 (above). Phylogenetic tree for Ino80. The Ino80 proteins segregate into a separate sub-family. (Bakshi et al., 2004).
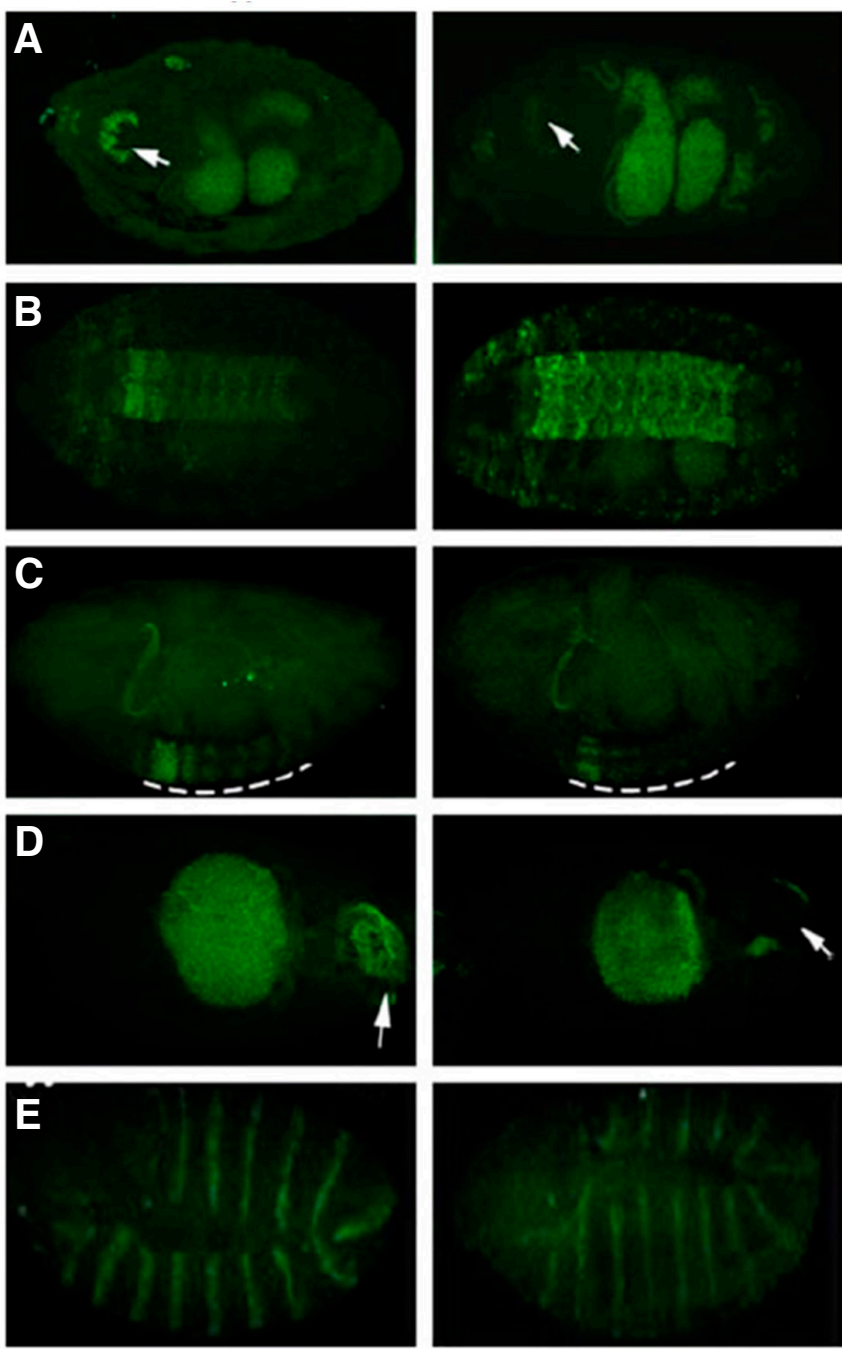

E value range $6 e-47$ to $3 e-13)$. The similarity scores drastically decreased beyond this stretch both on the $\mathrm{N}$ terminal and the $\mathrm{C}$ terminal end. The most significant feature of this domain designated DBINO domain (DNA Binding domain of INO80), is the occurrence of the positive amino acids arginine and lysine in tandem (RK/KR), in multiple positions, which are likely to bind DNA. Such motifs are also found in DNA binding proteins like chromosomal proteins D1 and HMG-1, mediating their interaction at A-T rich regions by contacts in the minor groove of DNA (Churchill et al., 1991; Ashley, et al., 1989). We predicted the secondary structure of the domain using various softwares such as NNPREDICT (Churchill et al., 1991), SOPMA (Ashley et al., 1989) and JPRED (Cuff et al., 1998). The predicted alpha helical segments are marked in Fig. 5B. Hydropathy analysis of the alpha helical segments identified three alpha helices as amphipathic wherein they expose hydrophilic side chains on one side of the helix and hydrophobic side chains on the opposite side. INO80 does not contain SANT or the Bromo domain. Based on these sequence features INO80-subfamily under the SNF2 super family was recognized (Fig. 6. Bakshi et al., 2004).

The first well characterized homologue is the yeast INO80 and its complex, identified in a screen for regulators of phospholipid biosynthesis (Shen et al., 2000). This INO80 complex is largely conserved in Drosophila and human (Klymenko et al., 2006 and Chen et al., 2011) and is considered as the canonical complex. The INO80 family functions in a diverse array of cellular processes, including DNA repair, cell cycle checkpoint, and telomere stability (Morrison and Shen, 2009). However, in the present context, we discuss the role of INO80 specifically in development.

The shared peptide identity between INO80, Brahma and ISWI, led us to examine if INO80 is involved in development. In Drosophila, Ino80 is essential for completion of development, null mutants of dlno80 do not proceed beyond late embryonic stage (Bhatia et al., 2010). We observed mis-expression of homeotic genes in Ino80 null mutants (Fig. 7). The genetic interaction studies from our group showed that Ino80 interacts with PcG as well as TrxG members (Fig. 8). Therefore, dlno80 was classified as an Enhancer of Polycomb and Trithorax protein (ETP). One of the attributes of an ETP protein is that it can act as a positive regulator of transcription through its interaction with Trithorax proteins/TRX complex or as a repressor through interaction with Polycomb proteins/PRC complex. It was demonstrated that dlno80 in fact acts as a positive regulator for Scr in the wing imaginal disc while it acts as a repressor for Scr in leg and salivary gland imaginal disc (Fig. 9, Ghasemi et. al., 2015).

Klymenko et al., (2006) identified dlno80 as a part of a complex that contains Pho (Pleiohomeotic) in Drosophila. The role of dlno80 in Drosophila and its interaction with PcG-TrxG complex is demonstrated by Bhatia et al. (2010) and Ghasemi et al., (2015). The interaction of transcription factors Yin Yang 1 (YY1; in mammals) and Pleiohomeotic (Pho; in D. melanogaster), with hINO80/ dlno80 is known (Klymenko et al., 2006 and Jin et al., 2005). In addition to Pho/YY1, the INO80 complex contains two AAA+ ATPases (ATPases associated with a variety of cellular activities) referred to as RUVBL1 and 2 (mammals) and Reptin and Pontin

Fig. 7. Mis-expression of homeotic genes in Ino80 null mutants. Stage 15-17 embryos with the genotype +/+ (wild type) and dlno80 $\Delta 4 /$ dlno8 $0^{\Delta 4}$ were immunostained with anti-Scr (A), anti-Antp (B), anti-Ubx (C) and anti-Abd-B (D) antibodies in independent experiments. Engrailed (En) is used as control. (Bhatia et al., 2010). 

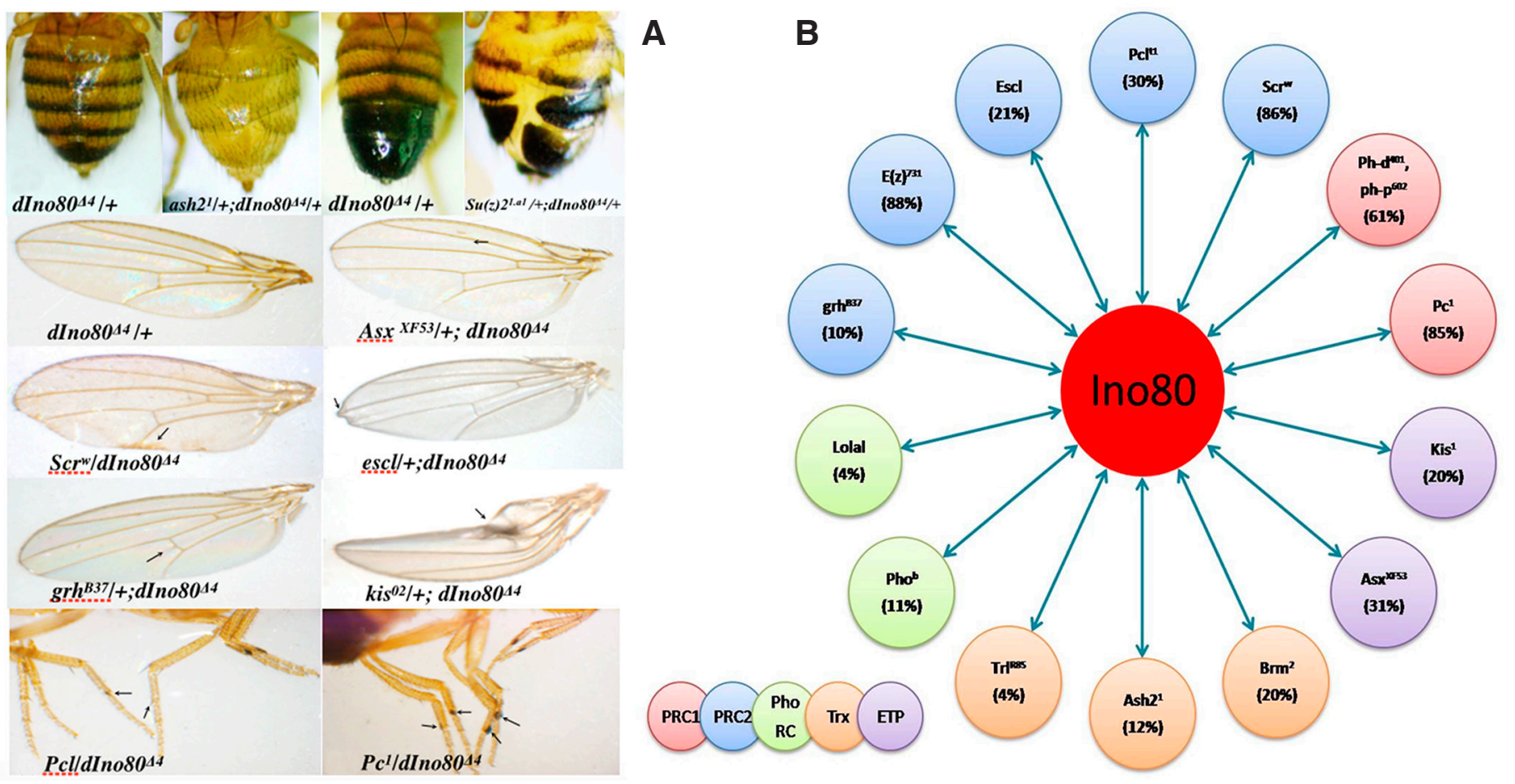

Fig. 8. Ino80 is an enhancer of polycomb and trithorax protein (ETP). Genetic interaction of dlno80 with polycomb, trithorax and also other ETP proteins is shown. (A) The phenotypes observed in selected cases. (B) All the interactions identified. (Ghasemi et al.2015)

(D. melanogaster). These three factors have well documented roles in embryonic development as members of PcG-TrxG proteins (Brown et al., 1998; Bellosta et al., 2005). Therefore, the canonical complex can also be recruited to regulatory site through YY1/Pho (Cai et al., 2007).

We demonstrated Pho independent function of dINO80 and also rescue of Pho null mutants which show lethality due to loss of Pho (Ghasemi et al., 2015, unpublished Jain et al., 2019). In another study, Neumen et al., (2014), isolated a point mutation in the ATPase domain and observed pupal lethality, attributed to altered expression of ecdysone induced genes (Neumen et al., 2014). The origin of this difference is not clear. The deletion maps at 12 th exon region and there is total absence of Ino80 transcripts (Unpublished). The INO80 complexes share many subunits with the mammalian BAF and fly BAP complexes like $\beta$-actin and several Arps (Actin-related proteins) (Olave et al., 2002; Szerlong et al., 2008). This sharing of subunits implicate a critical actin- or Arp4/8dependent role shared by INO80 and BAF complexes, possibly in targeting these complexes to structural elements (Gerhold et al., 2012, Nishimoto et al., 2012; Brahma et al., 2018; Knoll et al., 2018). The fact that yeast SWI/SNF complex lacks both Arp4 and actin indicates that the BAP and BAF complexes may have acquired additional functions that are not demonstrated by yeast SWI/SNF.

dlno80 null mutation results in lethality and mis-expression of homeotic genes and this can be a direct or an indirect effect. The direct effect of epigenetic complexes on development can be attributed to their interaction with PRE/TRE sequences in Drosophila leading to mis-expression of homeotic genes. Therefore, we have addressed the question whether dIno80 interacts with PRE/TRE sequences. dlno80 localizes to bxd-PRE as well as iab-7 PRE and also human PRE-PIK3C2B transgenic flies (Unpublished).

\section{Moonlighting functions of polycomb and trithorax members}

The functional diversity of PRC/TRX proteins arise due to their interaction with other proteins. $Y Y 1$ which is known to recruit repressive complexes, can also interact with activating complexes such as BAF to mediate transcriptional activation (Wang et al., 2018). Similarly, the GAGA factor and its human homologue, ThPok, are known to associate with repressive complex, leading to lower expression of target genes (Maini et al., 2017; Srivastava et al., 2018). On the other hand, there are examples of proteins that carryout two different cellular functions, utilizing different functional domains (Jeffery, 1999). There are different mechanisms leading to such functional diversity; utilization of different functional domains, variation in post-translational modification (PTM), differential cellular localization or by association with different protein partners. Among the PcG and TrxG proteins, one example of this is the function of MLL as a trithorax protein and also its function in cell cycle (Fig. 10).

MLL proteins contain multiple domains, including a motif for interaction with unmethylated CpG island and a domain (SET domain) for histone H3K4 methylation. While their role in Hox gene regulation is well known, an additional role of MLL1 in the regulation of cell proliferation independent of its SET domain related function is also identified (Yu et al., 1995; Ali et al., 2014). A reduced MLL1 function leads to cell cycle arrest at G1 phase or S phase and defective cytokinesis (Takeda et al., 2006; Liu et al., 2010 and Ali et al., 2014). Depletion of the components of WARD complex also show similar defects though at varying levels. The proteolytic cleavage of MLL generates $\mathrm{N}$-terminal (MLL-N) and C-terminal (MLL-C) fragments which together form 

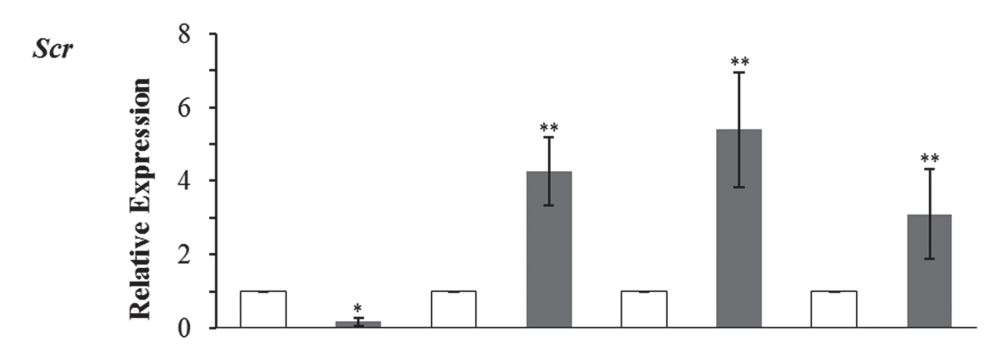

dIno80

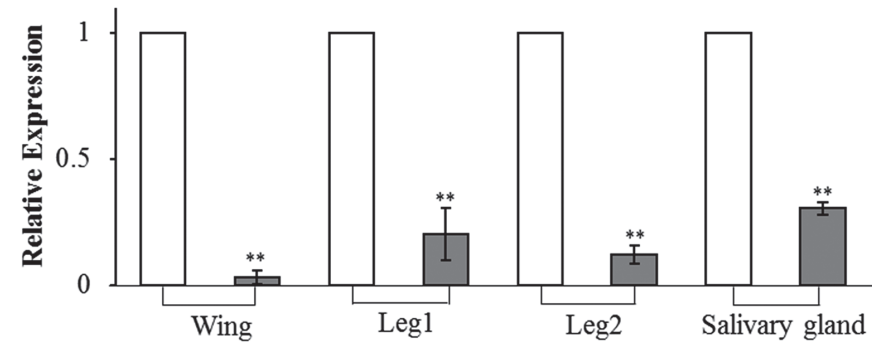

Fig. 9. Effect of dlno80 on Sex comb reduced (Scr) expression in imaginal disc. Both activating (wing disc) and repressive (Leg discs and salivary gland) effects of Ino80 were observed.(Ghasemi et al., 2015)

a stable complex, localizing in the nucleus, and stabilizing the $\mathrm{N}$-terminal which otherwise is degraded (Hsieh et al., 2002). The trans-activation domain of proteolytically cleaved MLL-C subunit is required for progression through $S$ phase whereas the WDR5 interacting motif (Win) is required for the proper mitotic progression. MLL-N subunit was found to be irrelevant to these functions of MLL1 (Ali et al., 2014). The cell cycle regulatory roles of MLL protein is totally independent of its SET domain related methyltransferase activity suggestive of a moonlighting function of MLL1 (Ali et al., 2014).

As mentioned earlier, members of INO80 subfamily contain a highly conserved DBINO domain, with potential DNA binding

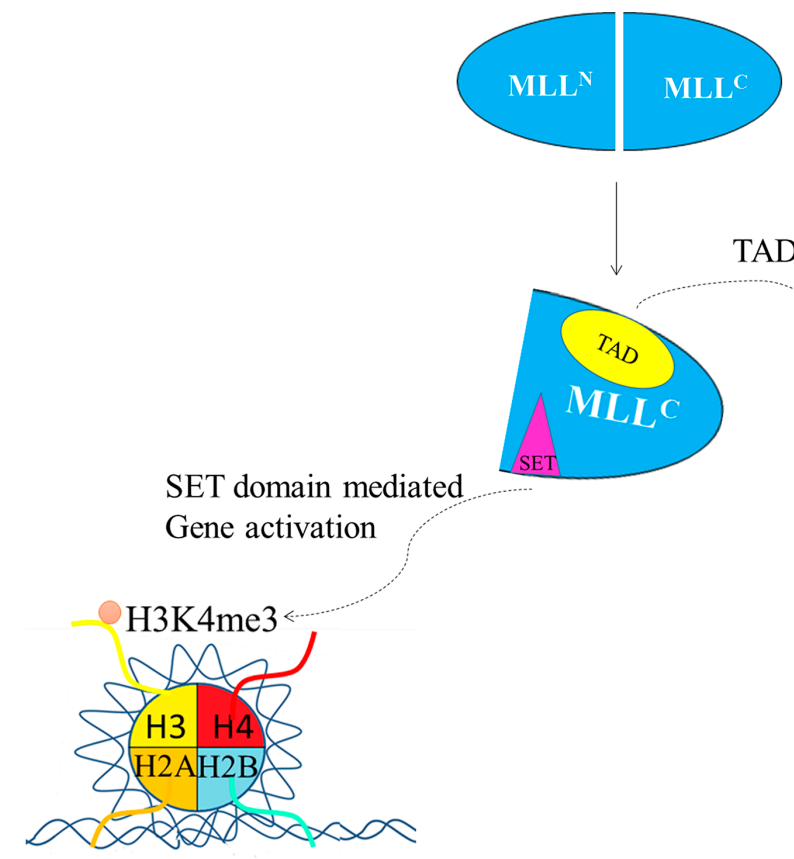

Activation of Transcription activity (Bakshi et al., 2004, 2006). This domain binds to a consensus sequence, thus having a DNA binding function and can act as recruiter of epigenetic regulatory complexes, a moonlighting function of INO80 and dIno80 (Mendiratta et al., 2016 and Jain et al., 2018).

The preferred motif for interaction of hlno80 with DNA is identified as 5'[CA][CA][CA][CG]GTCA[GC]CC3' sequence. We show that the localization of hINO80 in the upstream region is dependent on the presence of the DBINO binding DNA motif (Mendiratta et al., 2016). Through this motif hlno80 leads to the down regulation of the reporter sequence (Mendiratta et al., 2016). Similarly, the fly Ino80 recognizes the motif detected in human genome, but the affinity of dlno80 is higher for specific variants of the human consensus sequence. Unlike hINO80, dlno80 acts as a positive regulator of the reporter gene (Jain et al., 2019). The $\mathrm{Kd}$ for the variant sequence is in the range of 500 to $300 \mathrm{nM}$, which is considered as specificity indicator in other studies (Jain et al., 2019). With the recent evidence of the interaction of hINO80 with Ezh2 (Runge et al., 2018) and the proposition of non-canonical complex of INO80, it is possible that INO80 associates with different partners, forming a non-canonical complex that can interact with DNA (Fig. 11). This can be considered as a moonlighting function of INO80 (Fig. 12).

\section{Recruitment of epigenetic regulators to genomic sites: cis-elements in development}

Agene switch is a product of the interaction between trans-factors and the cis-elements. The recruitment of regulatory complexes to selected site on the genome, through defined DNA sequences, is critical to bring about specificity of activation and repression. In spite of the role of cis-elements being as important as the trans-acting factors, the attention on the discovery and functional characterization of cis-elements is limited in comparison to the trans-factors.

The cis-elements, with their unique binding affinities and interaction with different transcription factors and the nucleosomes, can define transcriptional behavior (Wittkopp and Kalay, 2011). The divergence of cis-regulatory sequence and hence, the activity may be correlated to the phenotypic evolution (Segal and Widom, 2009). Identification of the molecular mechanism that lead to the evolutionary gain of male-specific wing pigmentation spot in Drosophila biarmipes is an example of change in

Fig. 10. Moonlighting function of mixed lineage leukemia (MLL) protein. MLL protein is cleaved into the $\mathrm{N}$-terminal and C-terminal portions by Taspase 1 (a threonine aspartate). The C-terminal portion contains the SET domain that catalyzes the H3K4me3 and the Trans-Activation Domain (TAD) that plays a key role in cell cycle regulation. 
cis-regulatory elements leading to a sex specific phenotype during development (Gompel et al., 2005). The evolution of this spot is traced to the changes in the ancestral cis-regulatory element of the yellow pigmentation genes. Over the course of time this element gained multiple binding sites for transcription factors that are involved in wing development.

The cis-elements in Drosophila, are well studied in the context of Hox gene regulation. The mechanism of regulation involves the participation of a number of regulatory elements including, enhancers, insulators and Polycomb/Trithorax Responsive Elements (P/TRE) (Peifer et al., 1987; Akbari et al., 2006). The nomenclature suggesting that both the repressive (Polycomb) and activating (Trithorax) complexes can be recruited by these sequences (Chang et al., 1995; Orlando et al., 1998). This strategy of setting up a competition between two antagonistic outcomes through an overlapping/same cis-element(s) is an early invention in nature, as seen in phage lamda, in the choice between lytic and lysogenic pathways (Uetake et al., 1958; Echols et al., 1972).

In Drosophila melanogaster, a combination of maternal RNA and proteins activate a cascade of developmental genes leading to the establishment of segmentation pattern (Dworkin and Dworkin-Rastl, 1990). The anterio-posterior axis formation is brought about by Hox (homeotic) genes. The Drosophila Hox gene cluster comprises of two sub-clusters namely the antennapedia complex and the bithorax complex. The establishment of the segmental identity is under the control of a few genes, while a large number of regulatory elements within the Hox clusters are responsible for specific domain of expression and also the stage specific expression (Peifer et al., 1987; Akbari et al., 2006). The cis-regulatory infraabdominal regions (iab-2 to iab-8) control the expression of abdominal-A and Abdominal-B in parasegments (Sánchez-Herrero and Akam, 1989; Karch etal., 1990; Macías et al., 1990; Celniker et al., 1990; Gyurkovics et al., 1990; Boulet et al., 1991; Sánchez-Herrero, 1991; Crosby et al., 1993).

In Drosophila, the bithorax complex comprise of boundary elements (BE) that are closely associated with PREs and this association plays an important role in restricting ectopic expression (Singh and Mishra, 2015). The Mcp, Fab-7 and Fab-8 are examples of such associations. Deletions of these elements in Mcp as well as Fab7 , leads to ectopic expression of $A b d-B$ resulting in dorsal closure defect of the abdominal epithelia (DDA) (Singh and Mishra, 2015). The BE and PRE in the Mcp and Fab-7physically interact with each other as shown by the Chromosome Conformation Capture (3C) technique. Further, BE-PRE mediated repression is brought about by Polycomb Repressive Complex 1 (Singh and Mishra, 2015).

\section{Canonical polycomb silencing pathway: molecular mechanism}

The Polycomb complexes are known to interact with specific DNA sequences (Polycomb Response Elements - PREs) with the aid of transcription factors. The canonical pathway involves the recruitment of PRC2 complex at the PRE. The EZH2 protein in the PRC2 complex contains a SET domain that methylates H3K27 (H3K27me3). The PRC1 identifies the H3K27me3 and brings about H2AK119 monoubiquitylation (Cao et al., 2002; Wang et al., 2004; Buchwald et al., 2006). Later, it was shown that in mouse embryonic stem cells, PRC1 mediated monoubiquitylation of $\mathrm{H} 2 \mathrm{AK} 119$, promotes the recruitment of PRC2 complex that brings about H3K27me3 deposition (Cooper et al.2014). The PRC2 recruitment, in this case, is brought about by PRC1 variant and not the canonical PRC1 complex (Cooper et al., 2014). This illustrates the versatile nature of the complexes and the signals for their recruitment.

One of the pioneering studies to dissect the mechanism of epigenetic inheritance was performed using Drosophila as a model organism. Cavalli and Paro (1999) showed that Polycomb proteins as well as the Trithorax protein GAGA factor co-localize at the Fab7 element of the bithorax complex.

A

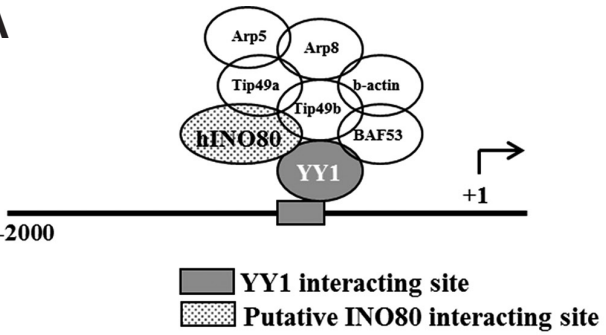

Fig. 11. A model for non-canonical complexes formed by Ino80. (A) The canonical complex known; (B) possible non-canonical complexes that could be present. For some functions Ino80 is recruited by YY1, while in others Ino80 can act has a recruiter. (Mendiratta et al., 2016).

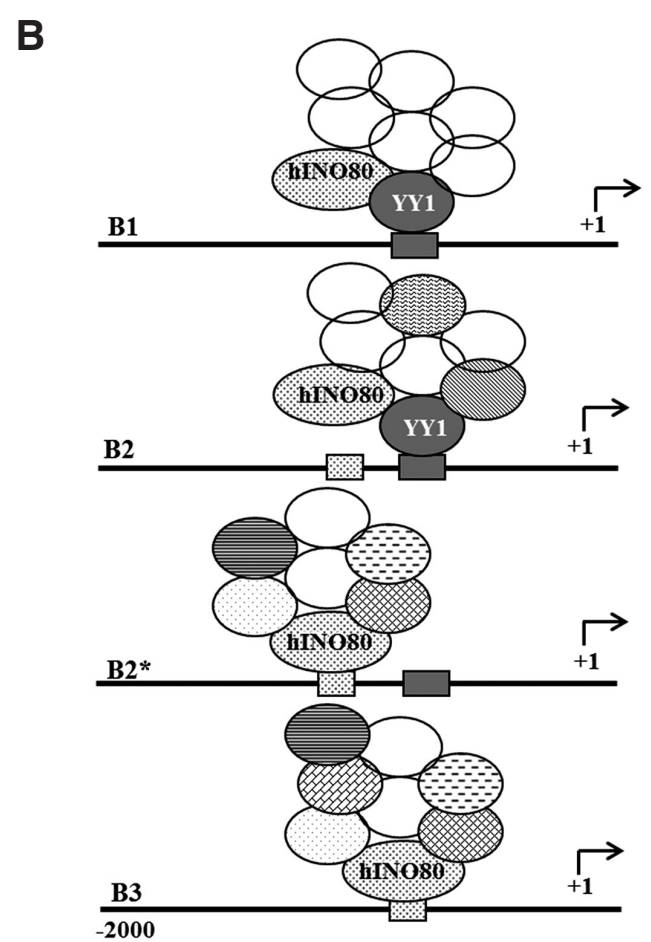

Further, using transgenic lines, with Fab-7 present upstream of the GAL4-driven lacZreporter and miniwhitegene, they demonstrated that Fab-7 element is sufficient to induce silencing of the reporter. However, a short pulse of GAL4 was sufficient to release the transgene from the PcG dependent silencing. The activated state was mitotically inherited and transmitted through a number of generations via meiosis. Thus, they established Fab-7 as a switch element. The hyperacetylation of histone $\mathrm{H} 4$ in the $\mathrm{Fab}-7$ region persisted after activation, suggesting that histone hyperacetylation is maintained through mitosis and might be a heritable epigenetic tag of the activated element (Cavalli and Paro, 1999). They further established that activated Fab-7drives the transcription of the gene even after the removal of the primary signal for transcription activation, in this 


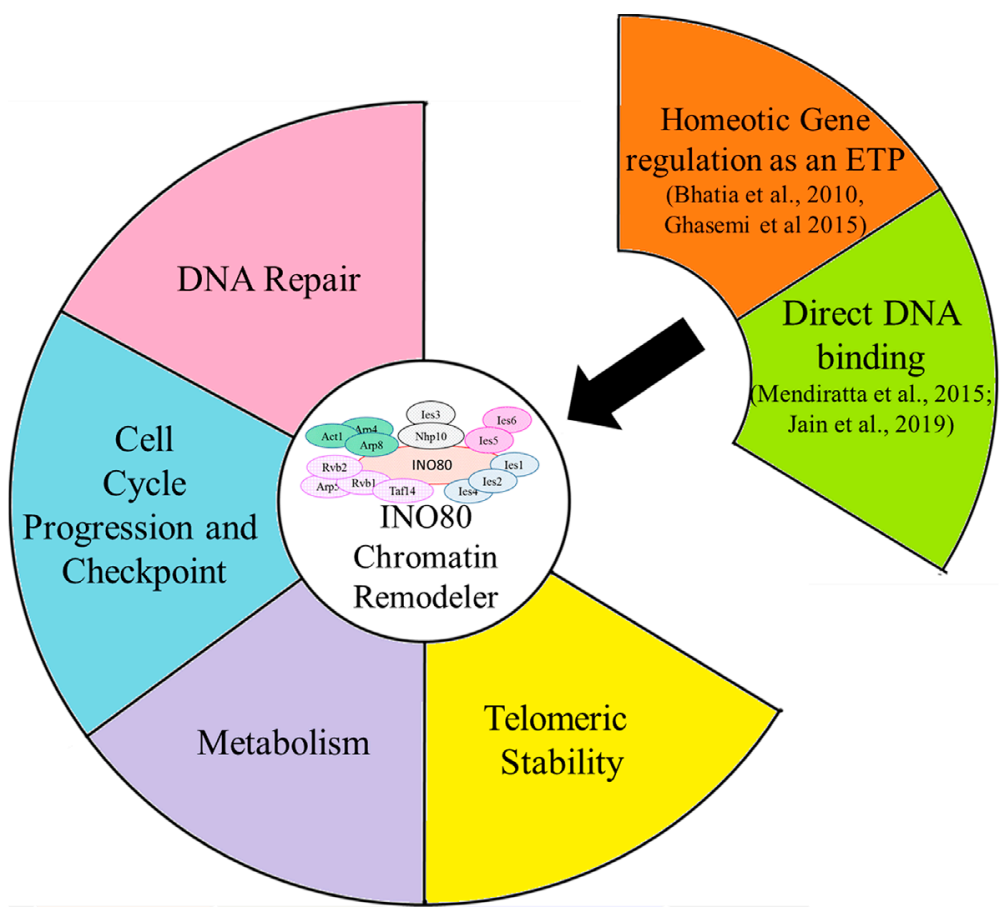

Fig. 12. Diversity in function of Ino80. The Ino80 protein is known to control/ play a key role in major molecular processes such as cell cycle progression, DNA repair, telomere stability and respiration. As discussed in this review INO80/ dlno80 regulates homeotic gene regulation as an Enhancer of Trithorax and Polycomb (ETP) group member. INO80 contains a DNA binding domain (DBINO) and regulates the transcription of reporter gene.

case, the Gal4. These cis-elements were recognized as PRE/TRE.

There are a number of reports of PREs/TREs in the Drosophila genome but only few are known in vertebrates. The best characterized PREs were identified in the bithorax complex (Simon et al., 1993) in Drosophila. In another study involving Drosophila, PREs/ TREs were distinguished from non-PRE sequences by analyzing pairwise combinations of seven motifs (Ringrose et al., 2003). Using this algorithm, 167 candidate PRE/TREs were identified in the BX-C (Bithorax Complex) and the ANT-C (Antennapedia Complex) (Ringrose et al., 2003). The majority of the PRE/TREs identified, mapped to genes involved in developmental processes. The candidate PREs were further validated for their interaction with PcG proteins in vivo and regulation of miniwhite expression in transgenic flies (Ringrose et al., 2003). The motifs significantly enriched in the candidate PREs include those for GAGA and Pho along with GTGT, PolyT and TGC triplets (Ringrose et al., 2003). Using a similar approach, a prediction tool was designed which utilizes the identification of clusters of individual motifs as well as multi-motif arrangements. The "jPREdictor" software assigns weightage to the occurrences of the motifs. The weightage or scores are derived from positive (sequence of known PREs) and negative training sets (non-PRE sequences; Fiedler and Rehmsmeier, 2006).

One of the few PRE/TREs known in vertebrates is PRE-Kr which regulates the expression of mouse Mafb/Kreislergene. Kr inversion brings about anteriorization of MafB expression by translocating a PRE from one rhombomere-specific gene to another gene thus, highlighting the role of PREs in long-range regulation of transcription (Sing et al., 2009). A study involving the analysis of chromatin architecture in the human embryonic stem cells reported the discovery of $1.8 \mathrm{~kb}$ region between HOXD11 and HOXD12 (D11.12) on chromosome 2, where PcG protein localizes. The repression of luciferase expression by the D11.12 element was dependent on BMI, EED and RYBP thus, establishing the D11.12 element as a PRE (Woo et al., 2010). Another PRE on chromosome 4 was identified in association with the FSHD (Facioscapulohumeral Muscular dystrophy) locus. The reduction in copy number of D4Z4 repeats is associated with the disease and acts as an epigenetic switch leading to de-repression of genes at the $4 \mathrm{q} 35$ region (Cabianca et al., 2012). D4Z4 responds to Polycomb complex and in healthy individuals, it acts as a PRE. In the FSHD patients, deletion of D4Z4 repeats causes activation of the genes including transcription of a long non-coding RNA, DBE-T that recruits Trithorax group protein, Ash1L to this locus (Cabianca et al., 2012).

\section{Mouse HoxD PRE interacts with heterochromatin factors}

A unique PRE was identified in the HoxD region based on its response to Polycomb protein by Vasanthi et al., (2013). It not only interacts with PcG/TrxG members but also with the heterochromatin proteins, Su(var)3-9, and $\mathrm{Su}(\mathrm{var}) 2-10$. Based on genetic interaction and cell culture assays, a $2 \mathrm{~kb}$ region interacting with PcG and Su(var) proteins was identified. The studies in transgenic flies in the background of $S u(v a r)$ mutations demonstrated the role of mouse HoxD PRE in heterochromatin-mediated repression. Further, TRL-GAF, a TrxG member and PC proteins were

shown to bind to different regions within the HoxD PRE (Vasanthi et al., 2013). The involvement of heterochromatin and PcG proteins in a switch between repression and activation at HoxD PRE region indicates a cross-talk between two distinct mechanisms to bring about transcription regulation; heterochromatin and PcG/TRL mediated repression/activation. Thus, it can be speculated that PREs may play a role in heterochromatin formation.

\section{Mining PRE/TRE from the human genome}

There are efforts to identify novel PRE/TRE in Drosophila and the human genome based on the conservation of the maintenance machinery. Since, the transcription factors (YY1 homologue of Pho) involved in the recruitment of PcG complexes are conserved across phyla, mapping the binding sites for the recruiters and their density of occurrence at a genomic loci is taken as predictor of potential $P R E$. This can be a genome-wide search or can be carried out on a selected genomic region. The availability of ENCODE ChIP-Seq data for histone modifications and transcription factors including PcG proteins (SUZ12, YY1, EZH2), has facilitated the identification of potential PRE/TREs in the human genome.

\section{Identification and characterization of human PRE-PIK3C2B}

hPRE-PIK3C2B was identified by mapping the binding site(s) for the transcription factors, that are known to recruit Polycomb complexes (YY1), on a set of genes that show altered expression 
in patients with $A L L[t(4: 11)]$, where ALL/MLL is a translocation partner. ALL/MLL/HRX gene (mapping of human chromosome 11q23), contains a domain similar to the trithorax gene, hence we focused on its putative target genes. The list of mis-expressed genes was retrieved from the microarray data of Armstrong et al., (2002). Following this, the regions upstream and downstream of the gene as well as the gene body of the selected gene set were analysed for YY1 binding sites. Depending on the density of YY1 motif sequences, the regions were selected for characterization. Out the top ten genes, PIK3C2B was selected, as it had a high density of YY1 and GAGA factor binding motifs in the first intron. This region was unique since it was repetitive in nature with $25 \mathrm{mer}$ sequence repeated 25 times (Bengani et al., 2013). Each 25mer unit had a YY1 binding motif (GCCAT) and a GAGA factor binding motif (GAGAG). It was of interest to note that we selected the same gene region using the PRE-dictor program that was trained on Drosophila data (Ringrose et al., 2003). The conservation was further borne out by the interaction of the PcG and TrxG proteins with hPRE-PIK3C2B in transgenic flies (Bengani et al., 2013).

In Drosophila, the control of reporter gene expression by Ubx $\mathrm{PRE} / \mathrm{TRE}$ is dependent on the competitive interactions of PC and TRX (Chang et al., 1995). In transgenic flies carrying a known PRE (the FAB fragment) adjacent to a GAL4 inducible reporter gene, competition between PcG-enabled repression and the GAL4induced activation is observed (Zink and Paro, 1995; Cavalli and Paro, 1998). The repressive landscape inhibits the interaction with activators but increased level of GAL4 trans-activator displaces PC from the ectopic binding sites (Zink and Paro, 1995).

The changes in the D4Z4 repeats associated with the FSHD locus in humans is another example of the transition between activation and repression due to altered cis-regualtory element (PRE to TRE-like function) that leads to FSHD (Cabianca et al., 2012).

The regulatory effect of $h P R E-P I K 3 C 2 B$ on the reporter as well as endogenous $P I K 3 C 2 B$ gene is dependent on the PRC2 complex members $Y Y 1$ and SUZ12. The number of repeating motifs for $Y Y 1$, has an effect on the level of repression of GFP reporter (Bengani et al., 2013). Correlating with the regulatory activity, there is YY1-dependent enrichment of PRC2 members (SUZ12, EZH2 and EED) and also H3K27me3 on hPRE-PIK3C2B (Bengani et al., 2013). One of the characteristics of PRE/TREs in Drosophila is PSS (Pairing Sensitive Silencing), which results when PREs are in homozygous condition (Kassis, 1994). To the best of our knowledge, $h P R E-P I K 3 C 2 B$ is the only mammalian PRE that shows PSS.

The PRE-TRE sequences in Drosophila overlap with each other, bringing in a competition between the PcG and TrxG complexes for binding and thus, tilting the balance between either positive and the negative regulation of the target genes (Chang et al., 1995; Zink and Paro, 1995). The PREs in Drosophila are also associated with Trx-dependent H3K4me2, thereby maintaining the expression of nearby developmental genes. Furthermore, the H3K4 dimethylation activity is conserved in MLL, the mammalian homologue of the Trx. MLL-mediated H3K4me2 mark is also associated with the $\mathrm{CpG}$ islands which can act as PREs. It was demonstrated that in the absence of MLL and H3K4me2, H3K27me3 increases at the CpG islands. In the absence of MLL, gene expression could be rescued by inhibiting PRC2-mediated H3K27me3 methylation (Rickels et al., 2016). Thus, there seems to be a balance between the MLL-mediated activation and PRC2- mediated repression.

Genetic interaction experiments using Drosophila transgenic lines show that $h P R E-P I K 3 C 2 B$ interacts not only with PcG members but also with TrxG members such as zeste and brm (Drosophila homologue of SMARCA2), an ATP-dependent chromatin remodeler, required for activation of homeotic genes (Maini et al., 2017, Tamkun et al., 1992). Maini et al. (2017), identified Trithorax group members such as MLL, MLL4, TH-POK and SET1 as proteins interacting with $h P R E-P I K 3 C 2 B$ based on affinity purification and mass spectrophotometry followed by validation using ChIP experiments. The tipping of the balance between activating and the repressive complex interaction is related to the abundance of the respective protein, as shown by knock-down experiments; $Y Y 1$ knockdown in cells or Pho mutation in the fly enhances the localization of MLL/Trx at $h P R E-P I K 3 C 2 B$ both in HEK cells and the transgenic fly which in turn leads to an increase in miniwhite expression (Maini et al., 2017).

\section{Minor and major polycomb response elements (PREs)}

The ChIP-seq data show that there are a number of strong peaks of PcG-protein enrichment in the Drosophilagenome which are characterized as PREs (De et al., 2016). Apart from the strong peaks, a number of weak peaks have been identified. The deletion of strong PREs associated with the invected-engrailed (inv-en) loci, does not alter the H3K27me3 domain, thereby maintaining the inv-en expression. Further, deletion of strong PREs does not affect the weak Pho and Ph peaks. More importantly, the deletion of strong PREs does not affect the 3D chromatin architecture of the PcG domain, which indicates that they have no role in maintaining the PcG domain (De et al., 2016). In contrast, the numerous weak Pho and $\mathrm{Ph}$ peaks are important for maintaining the repressive landscape. These observations show that, there can be another level of developmental gene regulation, that relates to affinity differences as a parameter which justifies the tipping of the balance between activation and repression.

\section{CpG islands, histone marks and polycomb responsiveness}

$\mathrm{CpG}$ islands are associated with the establishment of bivalent chromatin domains. There is a strong correlation between CpG islands and H3K4me3 mark. Genes without $\mathrm{CpG}$ islands are generally devoid of H3K27me3 or H3K4me3 mark. The genes with $\mathrm{CpG}$ islands are likely to carry bivalent histone marks and that the histone marks span the $\mathrm{CpG}$ islands precisely (Orlando et al., 2012). The GC-rich sequences are known to recruit Polycomb complexes (Mendenhall et al., 2010). The methylation status of the GC-rich sequences play an important role in Polycomb recruitment (Lynch et al., 2012).

\section{Role of long non-coding and short RNA in recruitment of polycomb complexes}

The role of the XIST, a long non-coding RNA, in X chromosome inactivation is well known. However, there are only a few examples of long non-coding RNAs participating in other developmental processes. HOTAIR, an anti-sense long non-coding RNA transcribed from $H O X C$ gene cluster, enhances PRC2 mediated epigenetic 
silencing by recruiting PRC2 to the target loci (Rinn et al., 2007). CBX7, a member of the PRC1 complex along with a non-coding RNAANRIL is upregulated in prostate cancer. The chromodomain of the CBX7 protein interacts with both the H3K27me3 as well as ANRIL RNA, and this interaction is required for repression at the INK4b/ARF/INK4a locus. Interfering with either of the interactions leads to growth arrest in Drosophila (Kotake et al., 2011).

A study using $\mathrm{X}$-inactivation as a model demonstrated that SUZ12 along with JARID2 and EZH2 binds to cis-acting RNAs (Tsix, HOTAIR and RepA); EZH2 shows the highest affinity and EED inhibit this interaction, while SUZ12 shows moderate affinity. The binding of RNA to EZH2 inhibits its methyltransferase activity. JARID2 plays a major role in disrupting this interaction thereby rescuing the methyltransferase activity (Cifuentes-Roja et al., 2014). The implied reversibility between inactive and active state is perhaps important in reactivation of inactive $\mathrm{X}$ chromosome during gametogenesis. The short RNAs transcribed from the 5' end of the Polycomb target genes form stem-loop structure promoting the recruitment of PRC2. During differentiation, these short RNAs are lost leading to activation (Kanhere et al., 2010).

In another example, PRC2 interacts with nascent RNA at all the active genes. PRC2 binds to regions spanning exon-intron boundaries and 3'UTR as shown by RNA cross-linking profiles. Furthermore, it was established that SUZ12 interacts with RNAand can bind to it even in the absence of other PRC2 members. PRC2 binding to the chromatin is mutually exclusive to its association to nascent RNA. The degradation of RNA increases the binding of PRC2 to the chromatin thus, it appears that the chromatin and RNA compete against each other to interact with PRC2 complex (Beltran et al., 2016)

\section{Polycomb response elements and chromatin organization}

The transcription repression is brought about by PRC1 by compaction of defined nucleosomal arrays (one PRC1 complex can compact 3 nucleosomes) (Francis et al., 2004). PRC1 is present in both diffused as well as in localized state and the localized sites appear as intensely fluorescent foci. Using the human U-2OS cells expressing BMI1-GFP protein, the PcG bodies have been identified as nuclear domains enriched with separate heterochromatin regions (Smigova et al., 2011). Recently, the Drosophila genome was classified into three major domains, the active, inactive and the Polycomb-repressed domain which vary in nucleosome packing and the polycomb-repressed domains show the highest nucleosome density. Polycomb-repressed domains tend to be more compact and are enriched in developmental genes (Wani et al., 2016). Polycomb Response Elements (PREs) as well as insulator elements are implicated in long-range chromatin interactions in Drosophila (Sigrist et al., 1997; Li et al., 2011). Thus, PREs bring about chromatin compaction and also play an important role in maintaining 3-dimensional chromatin organization.

\section{Distinguishing polycomb response elements}

A recent study by Du et al., (2018), identified three classes of response elements in the human genome namely the PREs, TREs and P/TREs on the basis of their distance from TSS, GC content, co-localization with $\mathrm{CpG}$ islands, endogenous gene targets and enrichment of transcription factors. A majority of the PREs are at a distance of 6-142 Kb from TSS whereas P/TREs are within 3-19Kb
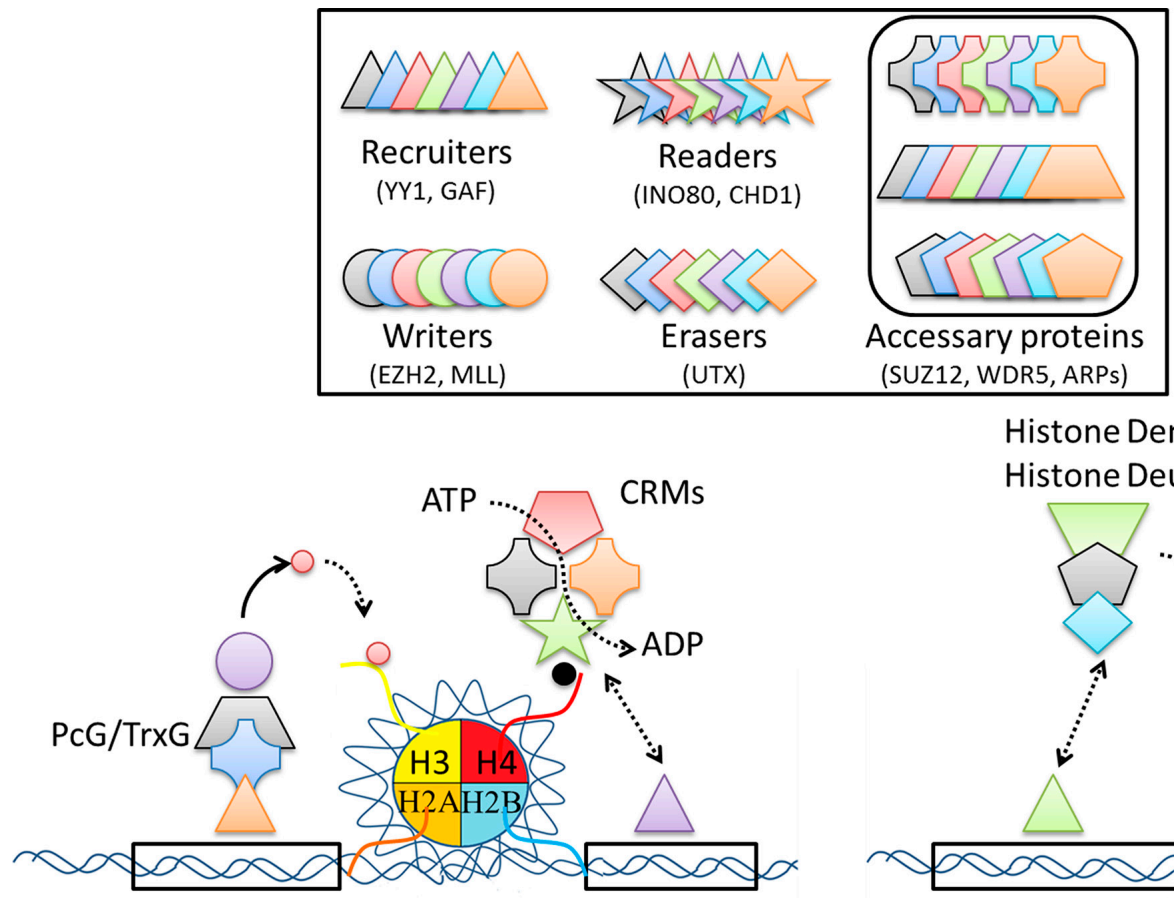

Histone Demethylases

Histone Deubiquitinase

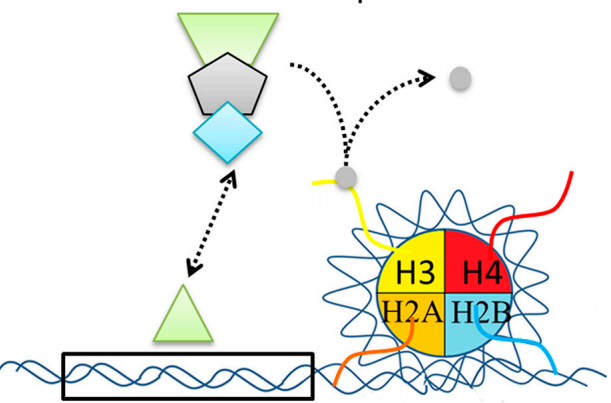

Fig. 13. A model for changing composition and function of epigenetic regulatory complexes; LEGO set model. The partners in these complexes are distinguished as Recruiters, Writers, Readers and Erasers, and Accessory proteins that enhance the reaction they catalyze. It is conceived that a relatively limited number of these non-redundant proteins of each functional class can interact to generate a large variety of unique complexes as in a LEGO set. These can target multiple genes or the same gene at temporally different stage and in different progenitor cells to maintain them in active or repressed state. 
of the TSS (Du et al., 2018). The TREs on the other hand, often overlap with the TSS. Furthermore, PREs often show higher GC content in comparison to TREs and often overlap with the $\mathrm{CpG}$ islands unlike PREs and P/TREs. The PREs and P/TREs analyzed by Du et al., (2018) targeted long non-coding RNA genes whereas the TREs targeted housekeeping genes. Interestingly $Y Y 1$ was found to be enriched at all the TREs but showed very low enrichment at the PREs. The literature so far reflect that the sites of interaction of epigenetic regulatory complexes are varied and there is scope for their localization at many positions along the genome.

\section{Epilogue}

The mechanism of regulation of developmental gene expression through epigenetic modifications is an example of the selection of a strategy to generate unique expression profiles in a sub-set of cells during development to bring about a distinct tissue/organ development. In a simplified view, a common set of tools, that include DNA motif recognizing proteins(recruiters), binding/interacting surfaces (ARPs), epigenetic writers (histone methyltransferases, acetylases,), readers (chromatin remodeling proteins, PRC1 members), erasers (demethylases, deacetylases) form complexes which not only regulate transcription, but also result in retaining the transcriptional memory through mitosis. The major advantage of the transcriptional memory mechanism through epigenetic modification of DNA and the histones is the interaction of a limited number of protein factors (with different biochemical functions) in complexes to generate not only distinct functional units/complexes, but also achieve unique regulatory outcomes. This makes it possible to have a limited number of protein-coding genes in spite of the increasing complexity of biological systems in the evolutionary time-line. Thus, it is comparable to a LEGO set, which can generate combinatorial assemblies to form unique complexes that can target specific genomic regions (Fig. 13). Added to this is the recent detection of moonlighting activity of some of the members of the PRC and TRX complexes that are reported (Ali et al., 2014).

Yet another step of resource-management that is being deciphered more recently is the long-range interaction of chromatin regions bringing genes with similar expression profiles together within a definable domain creating a hub. Such long-range interactions are known for many cis-elements (Sipos and Gyurkovics, 2005; Maksimenko and Georgiev, 2014) and we have detected both intra- and inter- chromosomal interactions of $h P R E-P I K 3 C 2 B$ through Circular Chromosome Conformation Capture (4C) analysis (unpublished results).

There are several new players such as TADs (Topologically Associated Domains), the CpG island as sites of PcG interaction and the cluster of enhancers (Super-enhancers) contributing to developmental regulation. The alteration of the active/repressive hubs is a part of the developmental programming. The mechanisms of bringing about such alterations remain to be deciphered.

\section{Acknowledgements}

This work was supported by grant from SERB, Government of India, No.60 (0102)/12/EMR-II). We acknowledge DBT Bioinformatics facility at ACBR, the UGC SAP-II (University Grants Commission), DU-DST_PURSE grant from University of Delhi. JM received Research Associate fellowship from SERB EMR/2016/000653/dt 15/03/2017) and AV from D.S. Kothari Fellowship from UGC and SK from, UGC, Government of India.

\section{References}

AGGER K, CLOOS PAC, CHRISTENSEN J, PASINI D, ROSE S, RAPPSILBER J, ISSAEVA I, CANAANI E, SALCINI AE, HELIN K (2007). UTX and JMJD3 are histone $\mathrm{H} 3 \mathrm{~K} 27$ demethylases involved in HOX gene regulation and development. Nature 449: 731-734.

AKBARI OS, BOUSUM A, BAE E, DREWELL RA (2006). Unraveling cis-regulatory mechanisms at the abdominal-Aand Abdominal-Bgenes in the Drosophilabithorax complex.Dev. Biol. 293: 294-304.

ALAM MP, DATTA S, MAJUMDAR S, MEHTAAK, BASKARAN S, GULATI N, BRAHMACHARI V (2010). Comparative analysis of DNA methylation in transgenic mice with unstable CGG repeats from FMR1 gene. Epigen. 5: 241-248.

ALI A, VEERANKI SN, TYAGI S (2014). A SET-domain-independent role of WRAD complex in cell-cycle regulatory function of mixed lineage leukemia.Nucleic Acids Res. 42: 7611-7624.

ANCELINK, SYXL, BORENSZTEIN M, RANISAVLJEVICN, VASSILEVI, BRISEÑOROA L, LIU T, METZGER E, SERVANT N, BARILLOT E, CHEN CJ, SCHÜLE R, HEARD E (2016). Maternal LSD1/KDM1A is an essential regulator of chromatin and transcription landscapes during zygotic genome activation. eLife 5:e08851.

ANG YS, TSAI SY, LEE DF, MONK J, SU J, RATNAKUMAR K, DING J, GE Y, DARR $\mathrm{H}$, CHANG B, WANG J, RENDL M, BERNSTEIN E, SCHANIEL C, LEMISCHKA IR (2011). Wdr5 mediates self-renewal and reprogramming via the embryonic stem cell core transcriptional network. Cell 145: 183-187.

ARAN D, TOPEROFF G, ROSENBERG M, HELLMAN A (2011). Replication timingrelated and gene body-specific methylation of active human genes. Human Molec. Genet. 20: 670-680.

ARDEHALI MB, MEI A, ZOBECK KL, CARON M, LIS JT, KUSCH T (2011). Drosophila Set 1 is the major histone $\mathrm{H} 3$ lysine 4 trimethyltransferase with role in transcription. EMBO J. 30: 2817-2828.

ARMSTRONG SA, STAUNTON JE, SILVERMAN LB, PIETERS R, DEN BOER ML, MINDEN MD, SALLAN SE, LANDER ES, GOLUB TR, KORSMEYER SJ (2002). MLL translocations specify a distinct gene expression profile that distinguishes a unique leukemia. Nature Genet. 30: 41-47.

ASHLEY CT, JENNINGS WW, SAXENA A, GLOVER C (1989). Isolation and Sequencing of cDNA Clones Encoding Drosophila Chromosomal Protein D1.J. Biol. Chem. 264: 8394-8401.

AYTON PM, CHEN EH, CLEARY ML (2004). Binding to Nonmethylated CpG DNA Is Essential for Target Recognition, Transactivation, and Myeloid Transformation by an MLL Oncoprotein. Molec. Cell. Biol. 24: 10470-10478.

AZUARA V, PERRY P, SAUER S, SPIVAKOVM, JØRGENSEN HF, JOHNRM, GOUTI M, CASANOVA M, WARNES G, MERKENSCHLAGER M, FISHER AG (2006). Chromatin signatures of pluripotent cell lines. Nature Cell Biol. 8: 532-538.

BAKIRI L, HAMACHER R, GRAÑA O, GUÍO-CARRIÓN A, CAMPOS-OLIVAS R, MARTINEZ L, DIENES HP, THOMSEN MK, HASENFUSS SC, WAGNER EF (2017). Liver carcinogenesis by FOS-dependent inflammation and cholesterol dysregulation. J. Exp. Med. 214: 1387-1409.

BAKSHI R, MEHTAAK, SHARMA R, MAITI S, PASHA S, BRAHMACHARI V (2006), Characterization of a human SWI2/SNF2 like protein hINO80: Demonstration of catalytic and DNA binding activity. Biochem. Biophys. Res. Commun. 339:313-320.

BAKSHIR, PRAKASHT, DASHD, BRAHMACHARIV (2004). In silico characterization of the INO80 subfamily of SWI2/SNF2 chromatin remodeling proteins. Biochem. Biophys. Res. Commun. 320: 197-204.

BANNISTERAJ, ZEGERMANP, PARTRIDGEJF, MISKAEA, THOMAS JO, ALLSHIRE RC, KOUZARIDES T (2001). Selective recognition of methylated lysine 9 on histone $\mathrm{H} 3$ by the HP1 chromo domain. Nature 410: 120-124.

BASKARAN S, DATTA S, MANDAL A, GULATI N, TOTEY SM, ANAND RR, BRAHMACHARI V (2002). Instability of CGG repeats in transgenic mice. Genomics 80: 151-157.

BASU A, TOMAR A, DASARI V, MISHRA RK, KHOSLA S (2016). DNMT3L enables accumulation and inheritance of epimutations in transgenic Drosophila. Sci. Rep. 6: 19572.

BAUMANN C, DE LA FUENTE R (2011). Role of polycomb group protein Cbx2/M33 in meiosis onset and maintenance of chromosome stability in the mammalian germline.Genes 2: 59-80.

BECKER JS, NICETTO D, ZARETKS (2016). H3K9me3-Dependent Heterochromatin: 
Barrier to Cell Fate Changes. Trends Genet. 32: 29-41.

BELLOSTA P, HULF T, DIOP S, USSEGLIO F, PRADEL J, ARAGNOL D, GALLANT $P$ (2005). Myc interacts genetically with Tip48/Reptin and Tip49/Pontin to control growth and proliferation during Drosophila development. Proc. Natl. Acad. Sci. USA 102: 11799-11804.

BELTRAN M, YATES CM, SKALSKA L, DAWSON M, REIS FP, VIIRI K, FISHER CL, SIBLEY CR, FOSTER BM, BARTKE T, ULE J, JENNER RG (2016). The interaction of PRC2 with RNA or chromatin s mutually antagonistic.Genome Res. 26: 896-907.

BENGANI H, MENDIRATTA S, MAINI J, VASANTHI D, SULTANA H, GHASEMI M, AHLUWALIA J, RAMACHANDRAN S, MISHRA RK, BRAHMACHARI V (2013). Identification and Validation of a Putative Polycomb Responsive Element in the Human Genome.PLoS ONE 8(6):e67217.

BERNSTEIN BE, MIKKELSEN TS, XIE X, KAMAL M, HUEBERT DJ, CUFF J, FRY B, MEISSNER A, WERNIG M, PLATH K, JAENISCH R, WAGSCHAL A, FEIL R, SCHREIBER SL, LANDER ES (2006). A Bivalent Chromatin Structure Marks Key Developmental Genes in Embryonic Stem Cells. Cell 125: 315-326.

BHATIA S, PAWAR H, DASARI V, MISHRA RK, CHANDRASHEKARAN S, BRAHMACHARI V (2010). Chromatin remodeling protein INO80 has a role in regulation of homeotic gene expression in Drosophila. Genes Cells 15: 725-735.

BIAN C, XU C, RUAN J, LEE KK, BURKE TL, TEMPEL W, BARSYTE D, LI J, WU M, ZHOU BO, FLEHARTY BE, PAULSON A, ALLALI-HASSANI A, ZHOU JQ, MER G, GRANT PA, WORKMAN JL, ZANG J, MIN J (2011). Sgf29 binds histone $\mathrm{H} 3 \mathrm{~K} 4 \mathrm{me} / 3$ and is required for SAGA complex recruitment and histone $\mathrm{H} 3$ acetylation. EMBO J. 30: 2829-2842.

BOCKER MT, TUORTO F, RADDATZ G, MUSCH T, YANG FC, XU M, LYKO F, BREILING A (2012). Hydroxylation of 5-methylcytosine by Tet2 maintains the active state of the mammalian Hoxa cluster. Nature Comm. 3:818.

BOULET AM, LLOYD A, SAKONJU S (1991). Molecular definition of the morphogenetic and regulatory functions and the cis-regulatory elements of the Drosophila Abd-B homeotic gene.Development 111: 393-405.

BRAHMAS, NGUBOM, PAULS, UDUGAMAM, BARTHOLOMEWB (2018). The Arp8 and Arp4 module acts as a DNA sensor controlling INO80 chromatin remodeling. Nature Comm. 9:3309.

BROWER-TOLAND B, RIDDLE NC, JIANG H, HUISINGA KL, ELGIN SCR (2009). Multiple SET methyltransferases are required to maintain normal heterochromatin domains in the genome of Drosophila melanogaster. Genetics 181: 1303-1319.

BROWN JL, MUCCI D, WHITELEY M, DIRKSEN ML, KASSIS JA (1998). The Drosophila polycomb group gene pleiohomeotic encodes a DNA binding protein with homology to the transcription factor YY1. Molec. Cell 1: 1057-1064.

BUCHWALD G, VAN DER STOOP P, WEICHENRIEDER O, PERRAKIS A, VAN LOHUIZEN M, SIXMA TK (2006). Structure and E3-ligase activity of the RingRing complex of Polycomb proteins Bmi1 and Ring1b.EMBO J. 25: 2465-2474.

BULTMAN S, GEBUHRT, YEE D, LA MANTIA C, NICHOLSON J, GILLIAM A, RANDAZZO F, METZGER D, CHAMBON P, CRABTREE G, MAGNUSON T (2000). A Brg1 null mutation in the mouse reveals functional differences among mammalian SWI/SNF complexes. Molec. Cell 6: 1287-1295.

BULTMAN SJ, GEBUHR TC, MAGNUSON T (2005). A Brg1 mutation that uncouples ATPase activity from chromatin remodeling reveals an essential role for SWI/ SNF-related complexes in b-globin expression and erythroid development. Genes Dev. 19: 2849-2861.

BULTMAN SJ, GEBUHR TC, PAN H, SVOBODA P, SCHULTZ RM, MAGNUSON T (2006). Maternal BRG1 regulates zygotic genome activation in the mouse. Genes Dev. 20: 1744-1754.

CABIANCA DS, CASA V, BODEGA B, XYNOS A, GINELLI E, TANAKA Y, GABELLINI D (2012). A long ncRNA links copy number variation to a polycomb/trithorax epigenetic switch in fshd muscular dystrophy. Cell 149: 819-831.

CAI Y, JIN J, YAO T, GOTTSCHALK AJ, SWANSON SK, WU S, SHI Y, WASHBURN MP, FLORENS L, CONAWAY RC, CONAWAY JW (2007). YY1 functions with INO80 to activate transcription. Nature Struc. Molec. Biol. 14: 872-874.

CAO R, WANG L, WANG H, XIA L, ERDJUMENT-BROMAGE H, TEMPST P, JONES RS, ZHANG Y (2002). Role of histone H3 lysine 27 methylation in polycomb-group silencing.Science 298: 1039-1043.

CAO R, ZHANG Y (2004). SUZ12 is required for both the histone methyltransferase activity and the silencing function of the EED-EZH2 complex. Molec. Cell15:57-67.

CAPUANO F, MÜLLEDER M, KOK R, BLOM HJ, RALSER M (2014). Cytosine DNA methylation is found in Drosophila melanogaster but absent in saccharomyces cerevisiae, schizosaccharomyces pombe, and other yeast species. Anal. Chem. 86: 3697-3702.

CAVALLI G, PARO R (1998). The Drosophila Fab-7 chromosomal element conveys epigenetic inheritance during mitosis and meiosis. Cell 93: 505-518.

CAVALLI G, PARO R (1999). Epigenetic inheritance of active chromatin after removal of the main transactivator. Science 286: 955-958.

CELNIKER SE, KEELAN DJ, LEWIS EB (1989). The molecular genetics of the bithorax complex of Drosophila: characterization of the products of the Abdominal-B domain. Genes Dev. 3: 1424-1436.

CHANDRASEKHARK, RAMANR (1997). De novo methylation of the proto-oncogene, $\mathrm{c}$-fos, during development occurs step-wise and directionally in the laboratory mouse. Molec. Reprod. Dev. 48: 421-432.

CHANG YL, KING BO, O'CONNOR M, MAZO A, HUANG DH (1995). Functional reconstruction of trans regulation of the Ultrabithorax promoter by the products of two antagonistic genes, trithorax and Polycomb. Mol Cell Biol.15(12):6601-1

CHEN L, CAI Y, JIN G, FLORENS L, SWANSON SK, WASHBURN MP, CONAWAY JW, CONAWAY RC (2011). Subunit organization of the human INO80 chromatin remodeling complex: An evolutionarily conserved core complex catalyzes ATPdependent nucleosome remodeling. J. Biol. Chem. 286: 11283-11289.

CHOULIARAS L, HOVE D van den (2012). Age-related increase in levels of 5-hydroxymethylcytosine in mouse hippocampus is prevented by caloric restriction. Curr. Alzheimer 9(5): 536-544.

CHURCHILL MEA, TRAVERS AA (1991). Protein motifs that recognize structural features of DNA. Trends Biochem. Sci. 16: 92-97.

CIFUENTES-ROJAS C, HERNANDEZ AJ, SARMA K, LEE JT (2014). Regulatory Interactions between RNA and Polycomb Repressive Complex 2.Molec. Cell 55: 171-185.

COOPER S, DIENSTBIER M, HASSAN R, SCHERMELLEH L, SHARIF J, BLACKLEDGE NP, DEMARCO V, ELDERKIN S, KOSEKI H, KLOSE R, HEGER A, BROCKDORFF N (2014). Targeting Polycomb to Pericentric Heterochromatin in Embryonic Stem Cells Reveals a Role for H2AK119u1 in PRC2 Recruitment. Cell Rep. 7: 1456-1470.

COTTON AM, PRICE EM, JONES MJ, BALATON BP, KOBOR MS, BROWN CJ (2015). Landscape of DNA methylation on the $X$ chromosome reflects $C p G$ density, functional chromatin state and X-chromosome inactivation. Human Molec. Genet. 24: 1528-1539.

CROSBY MA, LUNDQUIST EA, TAUTVYDAS RM, JOHNSON JJ (1993). The 3' regulatory region of the Abdominal-B gene: Genetic analysis supports a model of reiterated and interchangeable regulatory elements. Genetics 134: 809-824.

CUFF JA, CLAMP ME, SIDDIQUI AS, FINLAY M, BARTON GJ (1998). JPred: A consensus secondary structure prediction server. Bioinformatics 14: 892-893.

DAHLE Ø, KUMAR A, KUEHN MR (2010). Nodal signaling recruits the histone demethylase Jmjd3 to counteract Polycomb-mediated repression at target genes. Science Sig. 3(127):ra48.

DAVIDSON EH, RAST JP, OLIVERI P, RANSICK A, CALESTANI C, YUH CH, MINOKAWA T, AMORE G, HINMAN V, ARENAS-MENA C, et al., (2002). A genomic regulatory network for development. Science 295: 1669-1678.

DE S, MITRAA, CHENG Y, PFEIFER K, KASSIS JA (2016). Formation of a PolycombDomain in the Absence of Strong Polycomb Response Elements.PLoS Genet. 12(7): e1006200.

DÉJARDIN J, CAVALLI G (2004). Chromatin inheritance upon Zeste-mediated Brahma recruitment at a minimal cellular memory module.EMBO J. 23: 857-868.

DENISSOV S, HOFEMEISTER H, MARKS H, KRANZ A, CIOTTA G, SINGH S, ANASTASSIADIS K, STUNNENBERG HG, STEWART AF (2014). MII2 is required for H3K4 trimethylation on bivalent promoters in embryonic stem cells, whereas MII1 is redundant. Development 141: 526-537.

DESHMUKH S, PONNALURI VC, DAI N, PRADHAN S, DEOBAGKAR D (2018) Levels of DNA cytosine methylation in the Drosophila genome. PeerJ 6: e5119.

DHAR SS, LEE SH, CHEN K, ZHU G, OH WK, ALLTON K, GAFNI O, KIM YZ, TOMOIGA AS, BARTON MC, HANNA JH, WANG Z, LI W, LEE MG (2016). An essential role for UTX in resolution and activation of bivalent promoters. Nuc. Acid. Res. 44: 3659-3674.

DU J, JOHNSON LM, JACOBSEN SE, PATEL DJ (2015). DNA methylation pathways and their crosstalk with histone methylation. Nature Rev. Molec. Cell Biol. 16: 
$519-532$

DUKERS DF, VAN GALEN JC, GIROTH C, JANSEN P, SEWALT RGAB, OTTE AP, KLUIN-NELEMANS HC, MEIJER CJLM, RAAPHORST FM (2004). Unique Polycomb Gene Expression Pattern in Hodgkin's Lymphoma and Hodgkin's Lymphoma-Derived Cell Lines. Am. J. Pathol. 164: 873-881.

DWORKIN MB, DWORKIN-RASTL E (1990). Functions of maternal mRNA in early development.Molec. Reprod. Dev. 26: 261-297.

ECHOLS H (1972). Developmental Pathways for the Temperate Phage: Lysis VS Lysogeny. Ann. Rev. Genet. 6: 157-190.

ENDERLE D, BEISEL C, STADLER MB, GERSTUNG M, ATHRI P, PARO R (2011). Polycomb preferentially targets stalled promoters of coding and noncoding transcripts. Genome Res. 21: 216-226.

ERNST P, VAKOC CR (2012). WRAD: Enabler of the SET1-family of H3K4 methyltransferases. Briefing. Func. Genome 11: 217-226.

ERNST P, VAKOC CR (2012). WRAD: Enabler of the SET1-family of H3K4 methyltransferases. Briefing. Func. Genome11: 217-226.

FAN G, BEARD C, CHEN RZ, CSANKOVSZKI G, SUN Y, SINIAIA M, BINISZKIEWICZ D, BATES B, LEE PP, KÜHN R, TRUMPP A, POON C-S, WILSON CB, JAENISCH R (2001). DNA Hypomethylation Perturbs the Function and Survival of CNS Neurons in Postnatal Animals. J. Neurosci. 21: 788-797.

FANG R, CHEN F, DONG Z, HU D, BARBERAAJ, CLARK EA, FANG J, YANG Y, MEI P, RUTENBERG M, et al., (2013). LSD2/KDM1B and Its Cofactor NPAC/GLYR1 Endow a Structural and Molecular Model for Regulation of H3K4 Demethylation. Molec. Cell 49: 558-570.

FENG Q1, WANG H, NG HH, ERDJUMENT-BROMAGE H, TEMPST P, STRUHL $\mathrm{K}$, ZHANG Y. (2002). Methylation of H3-lysine 79 is mediated by a new family of HMTases without a SET domain. Curr. Biol. 12:1052-8.

FICZ G, BRANCO MR, SEISENBERGER S, SANTOS F, KRUEGER F, HORE TA, MARQUES CJ, ANDREWS S, REIK W (2011). Dynamic regulation of 5-hydroxymethylcytosine in mouse ES cells and during differentiation. Nature 473: 398-404.

FIELDER T, REHMSMEIER M (2006). jPREdictor: A versatile tool for the prediction of cis-regulatory elements. Nucleic Acid. Res. 34: W546-W550.

FRAPPORTI A, MIRÓ PINA C, ARNAIZ O, HOLOCH D, KAWAGUCHIT, HUMBERT A, ELEFTHERIOU E, LOMBARD B, LOEW D, SPERLING L, GUITOT K, MARGUERON R, DUHARCOURT S (2019). The Polycomb protein Ezl1 mediates $\mathrm{H} 3 \mathrm{~K} 9$ and H3K27 methylation to repress transposable elements in Paramecium. Nature Comm. 10:2710.

FUKS F, HURD PJ, WOLF D, NAN X, BIRD AP, KOUZARIDES T (2003). The methylCpG-binding protein MeCP2 links DNA methylation to histone methylation. J. Biol. Chem. 278: 4035-4040.

GAO Z, ZHANG J, BONASIO R, STRINO F, SAWAI A, PARISI F, KLUGER Y, REINBERG D (2012). PCGF Homologs, CBX Proteins, and RYBP Define Functionally Distinct PRC1 Family Complexes. Molec. Cell 45: 344-356.

GERHOLD CB, WINKLER DD, LAKOMEK K, SEIFERT FU, FENN S, KESSLER B, WITTE G, LUGER K, HOPFNER KP (2012). Structure of Actin-related protein 8 and its contribution to nucleosome binding. Nucleic Acid. Res. 40: 11036-11046.

GHASEMI M, PAWAR H, MISHRA RK, BRAHMACHARI V (2015). The functional diversity of Drosophila Ino80 in development. Mech. Dev. 138: 113-121.

GIBSON WT, HOOD RL, ZHAN SH, BULMAN DE, FEJES AP, MOORE R, MUNGALL AJ, EYDOUX P, BABUL-HIRJIR, AN J, MARRAMA, CHITAYATD, BOYCOTT KM, WEAVER DD, JONES SJM (2012). Mutations in EZH2 cause weaver syndrome. Am. J. Hum. Genet. 90: 110-118.

GOKUL G, GAUTAMI B, MALATHI S, SOWJANYA AP, POLI UR, JAIN M, RAMAKRISHNA G, KHOSLAS (2007). DNA methylation profile at the DNMT3L promoter: A potential biomarker for cervical cancer. Epigenetics 2: 80-85.

GOMPELN, PRUD'HOMME B, WITTKOPPPJ, KASSNER VA, CARROLLSB (2005). Chance caught on the wing: cis-regulatory evolution and the origin of pigment patterns in Drosophila. Nature 433: 481-487.

GOWHER H, LEISMANN O, JELTSCH A (2000). DNA of Drosophila melanogaster contains 5-methylcytosine. EMBO J. 19: 6918-6923.

GREER EL, BLANCO MA, GU L, SENDINC E, LIU J, ARISTIZÁBAL-CORRALES D, HSU CH, ARAVIND L, HE C, SHI Y (2015). DNA methylation on N6-adenine in C. elegans.Cell 161: 868-878.

GU TP, GUO F, YANG H, WU HP, XU GF, LIU W, XIE ZG, SHI L, HE X, JIN SG, IQBAL K, SHI YG, DENG Z, SZABÓ PE, PFEIFER GP, LI J, XU GL (2011). The role of Tet3 DNA dioxygenase in epigenetic reprogramming by oocytes. Nature 477: 606-612.

GUENTHER MG, JENNER RG, CHEVALIER B, NAKAMURA T, CROCE CM CANAANI E, YOUNG RA (2005). Global and Hox-specific roles for the MLL1 methyltransferase.Proc. Natl. Acad. Sci. USA 102: 8603-8608.

GYURKOVICS H, GAUSZJ, KUMMER'J, KARCHF, AKAM M (1990). Anew homeotic mutation in the Drosophila bithorax complex removes a boundary separating two domains of regulation. EMBO J. 9(8): 2579-2585.

HASHIMOTO H, HORTON JR, ZHANG X, BOSTICK M, JACOBSEN SE, CHENG X (2008). The SRA domain of UHRF1 flips 5-methylcytosine out of the DNA helix. Nature 455: 826-829.

HASHIMOTO H, HORTON JR, ZHANG X, CHENG X (2009). UHRF1, a modular multi-domain protein, regulates replication-coupled crosstalk between DNA methylation and histone modifications. Epigenetics 4: 8-14.

HELLMAN A, CHESS A (2007). Gene body-specific methylation on the active $X$ chromosome.Science 315: 1141-1143.

HENIKOFF S, GREALLY JM (2016). Epigenetics, cellular memory and gene regulation.Curr. Biol. 26: R644-R648.

HEYN H, ESTELLER M (2015). An adenine code for DNA: A second life for N6methyladenine. Cell 161: 710-713.

HSIEH JJ-D, ERNST P, ERDJUMENT-BROMAGE H, TEMPST P, KORSMEYER SJ (2002). Proteolytic Cleavage of MLL Generates a Complex of N- and C-Terminal Fragments That Confers Protein Stability and Subnuclear Localization. Molec. Cell. Biol. 23: 186-194.

HYUN K, JEON J, PARK K, KIM J (2017). Writing, erasing and reading histone lysine methylations. Exp. Molec. Med. 49(4):e324.

JACKSON M, KRASSOWSKA A, GILBERT N, CHEVASSUT T, FORRESTER L, ANSELL J, RAMSAHOYE B (2004). Severe Global DNA Hypomethylation Blocks Differentiation and Induces Histone Hyperacetylation in Embryonic Stem Cells. Molec. Cell. Biol. 24: 8862-8871.

JAINS, BHATTACHARYYAK, BAKSHIR, NARANGA, BRAHMACHARIV (2017). Distinguishing between biochemical and cellular function: Are there peptide signatures for cellular function of proteins? Proteins: Struc. Func. Bioinform. 85: 682-693.

JAIN S, MAINI J, NARANG A, MAITI S, BRAHMACHARI V (2019) The regulatory function of dlno80 correlates with its DNA binding activity. bioRxiv 519959; doi: https://doi.org/10.1101/519959

JEFFERY CJ (1999).Moonlighting proteins. Trends Biochem. Sci. 24: 8-11.

JIANG H, SHUKLA A, WANG X, CHEN WY, BERNSTEIN BE, ROEDER RG (2011). Role for Dpy-30 in ES cell-fate specification by regulation of H3K4 methylation within bivalent domains. Cell 144: 513-525.

JIN J, CAI Y, YAO T, GOTTSCHALK AJ, FLORENS L, SWANSON SK, GUTIÉRREZ JL, COLEMAN MK, WORKMAN JL, MUSHEGIAN A, WASHBURN MP, CONAWAY RC, CONAWAY JW (2005). A mammalian chromatin remodeling complex with similarities to the yeast INO80 complex. J. Biol. Chem. 280: 41207-41212.

KAHN TG, DORAFSHAN E, SCHULTHEIS D, ZARE A, STENBERG P, REIM I, PIRROTTA V, SCHWARTZ YB (2016). Interdependence of PRC1 and PRC2 for recruitment to Polycomb Response Elements. Nucleic Acid. Res. 44: 10132-10149.

KANEDA M, OKANO M, HATA K, SADO T, TSUJIMOTO H, LI E, SASAKI H (2004). Essential role for de novo DNA methyltransferase Dnmt3a in paternal and maternal imprinting. Nature 429: 900-903.

KANHERE A, VIIRI K, ARAÚJO CC, RASAIYAAH J, BOUWMAN RD, WHYTE WA, PEREIRA CF, BROOKES E, WALKER K, BELL GW, POMBO A, FISHER AG, YOUNG RA, JENNER RG (2010). Short RNAs Are Transcribed from Repressed Polycomb Target Genes and Interact with Polycomb Repressive Complex-2. Molec. Cell 38: 675-688.

KARCH F, BENDER W, WEIFFENBACH B (1990). AbdA expression in Drosophila embryos.Genes Dev. 4: 1573-1587.

KASSIS JA (1994). Unusual properties of regulatory DNA from the Drosophila engrailed gene: Three "pairing-sensitive" sites within a 1.6-kb region. Genetics 136: 1025-1038.

KASSIS JA, KENNISON JA, TAMKUN JW (2017). Polycomb and trithorax group genes in Drosophila. Genetics 206: 1699-1725.

KAWADA H, NISHIYAMA C, TAKAGI A, TOKURA T, NAKANO N, MAEDA K, MAYUZUMI N, IKEDA S, OKUMURA K, OGAWA H (2005). Transcriptional regulation of ATP2C1 gene by $\mathrm{Sp} 1$ and $\mathrm{YY} 1$ and reduced function of its promoter in Hailey- 
Hailey disease keratinocytes.J. Invest. Dermatol. 124: 1206-1214.

KENNISON JA, TAMKUN JW (1988). Dosage-dependent modifiers of polycomb and antennapedia mutations in Drosophila. Proc. Natl. Acad. Sci. USA 85:8136-8140.

KIM HG, KURTH I, LAN F, MELICIANI I, WENZEL W, EOM SH, KANG GB, ROSENBERGER G, TEKIN M, OZATA M, BICK DP, SHERINS RJ, WALKER SL, SHI Y, GUSELLA JF, LAYMAN LC (2008). Mutations in CHD7, Encoding a ChromatinRemodeling Protein, Cause Idiopathic Hypogonadotropic Hypogonadism and Kallmann Syndrome.Am. J. Hum. Genet. 83: 511-519.

KINGSTON RE, TAMKUN JW (2014).Transcriptional regulation by trithorax-group proteins. CSH Persp. Biol. 6(10): a019349.

KLAUKE K, RADULOVIĆ V, BROEKHUIS M, WEERSING E, ZWART E, OLTHOF S, RITSEMA M, BRUGGEMAN S, WU X, HELIN K, BYSTRYKH L, DE HAAN G (2013). Polycomb Cbx family members mediate the balance between haematopoietic stem cell self-renewal and differentiation. Nature Cell Biol. 15: 353-362.

KLYMENKO T, JÜRG M (2004). The histone methyltransferases Trithorax and Ash1 prevent transcriptional silencing by Polycomb group proteins. EMBO Rep. 5: 373-377.

KLYMENKO T, PAPP B, FISCHLE W, KÖCHER T, SCHELDER M, FRITSCH C, WILD B, WILM M, MÜLLER J (2006). A polycomb group protein complex with sequence-specific DNA-binding and selective methyl-lysine-binding activities. Genes Dev. 20: 1110-1122.

KNOLL KR, EUSTERMANN S, NIEBAUER V, OBERBECKMANN E, STOEHR G, SCHALL K, TOSI A, SCHWARZ M, BUCHFELLNER A, KORBER P, HOPFNER KP (2018). The nuclear actin-containing Arp8 module is a linker DNA sensor driving INO80 chromatin remodeling. Nature Struct. Molec. Biol. 25: 823-832.

KO M, BANDUKWALA HS, AN J, LAMPERTI ED, THOMPSON EC, HASTIE R, TSANGARATOU A, RAJEWSKY K, KORALOV SB, RAO A (2011). Ten-ElevenTranslocation 2 (TET2) negatively regulates homeostasis and differentiation of hematopoietic stem cells in mice. Proc. Natl. Acad. Sci. USA 108: 14566-14571.

KOSHOT, MIYAKE N, CAREY JC (2014). Coffin-Siris syndrome and related disorders involving components of the BAF (mSWI/SNF) complex: Historical review and recent advances using next generation sequencing. Am. J. Med. Genet, Part C: Sem. Med. Genet. 166: 241-251.

KOSHO T, OKAMOTO N, IMAI Y, OHASHI H, VAN EERDE AM, CHRZANOWSKA K, CLAYTON-SMITH J, KINGSTON H, MARI F, AGGARWAL S, et al., (2014). Genotype-phenotype correlation of coffin-siris syndrome caused by mutations in SMARCB1, SMARCA4, SMARCE1, and ARID1A. Am. J. Med. Genet, Part C: Sem. Med. Genet. 166: 262-275.

KOTAKE Y, NAKAGAWA T, KITAGAWA K, SUZUKI S, LIU N, KITAGAWA M, XIONG $Y$ (2011). Long non-coding RNA ANRIL is required for the PRC2 recruitment to and silencing of p15 INK4B tumor suppressor gene. Oncogene 30: 1956-1962.

KRAAN CM, GODLER DE, AMOR DJ (2019). Epigenetics of fragile $X$ syndrome and fragile X-related disorders. Dev. Med. Child Neurol. 61: 121-127.

LAHERTY CD, YANG WM, JIAN-MIN S, DAVIE JR, SETO E, EISENMAN RN (1997). Histone deacetylases associated with the mSin3 corepressor mediate Mad transcriptional repression. Cell 89: 349-356.

LEWIS EB (2007). A gene complex controlling segmentation in Drosophila. In Genes, Development, and Cancer: The Life and Work of Edward B. Lewis pp. 229-242.

LI E, BESTOR TH, JAENISCH R (1992). Targeted mutation of the DNA methyltransferase gene results in embryonic lethality. Cell 69: 915-926.

LIH-B, MULLER M, BAHECHAR IA, KYRCHANOVAO, OHNOK, GEORGIEV P, PIRROTTA V (2011). Insulators, Not Polycomb Response Elements, Are Required for Long-Range Interactions between Polycomb Targets in Drosophila melanogaster. Molec. Cell. Biol. 31(4):616-25.

LIEDTKE M, CLEARY ML (2009). Review article Therapeutic targeting of MLL. Hematology 113(24):6061-6068.

LIUH, TAKEDAS, KUMARR, WESTERGARDTD, BROWNEJ, PANDITATK, CHENG EHY, HSIEH JJD (2010). Phosphorylation of MLL by ATR is required for execution of mammalian S-phase checkpoint. Nature 467: 343-346.

LYNCH MD, SMITH AJH, DE GOBBI M, FLENLEY M, HUGHES JR, VERNIMMEN D, AYYUB H, SHARPE JA, SLOANE-STANLEY JA, SUTHERLAND L, MEEK S, BURDON T, GIBBONS RJ, GARRICK D, HIGGS DR (2012). An interspecies analysis reveals a key role for unmethylated CpG dinucleotides in vertebrate Polycomb complex recruitment. EMBO J. 31: 317-329.

MACIAS ANA, CASANOVA J, MORATA G (1990). Expression and regulation of the abd-A gene of Drosophila. Development 110: 1197-1207.
MAHMOUDI T, VERRIJZER CP (2001). Chromatin silencing and activation by Polycomb and trithorax group proteins. Oncogene 20: 3055-3066.

MAINI J, GHASEMI M, YANDHURI D, THAKUR SS, BRAHMACHARI V (2017). Human PRE-PIK3C2B, an intronic cis-element with dual function of activation and repression.Biochim. Biophys. Acta - Gene Reg. Mech. 1860: 196-204.

MAKSIMENKO O, GEORGIEV P (2014). Mechanisms and proteins involved in longdistance interactions. Frontiers Genet. 5: 28.

MANSOUR AA, GAFNI O, WEINBERGER L, ZVIRAN A, AYYASH M, RAIS Y, KRUPALNIK V, ZERBIB M, AMANN-ZALCENSTEIN D, MAZA I, GEULA S, VIUKOV S, HOLTZMAN L, PRIBLUDAA, CANAANI E, HORN-SABAN S, AMIT I, NOVERSHTERN N, HANNA JH (2012). The H3K27 demethylase Utx regulates somatic and germ cell epigenetic reprogramming. Nature 488: 409-413.

MARMORSTEIN R, ZHOU MM (2014). Writers and readers of histone acetylation: Structure, mechanism, and inhibition. Cold Spring Harb Perspect Biol 6: a018762

MELLÉN M, AYATA P, DEWELLS, KRIAUCIONIS S, HEINTZN (2012). MeCP2 binds to $5 \mathrm{hmC}$ enriched within active genes and accessible chromatin in the nervous system. Cell 151: 1417-1430.

MENDENHALL EM, KOCHE RP, TRUONG T, ZHOU VW, ISSAC B, CHI AS, KU M, BERNSTEIN BE (2010). GC-rich sequence elements recruit PRC2 in mammalian ES cells. PLoS Genet. 6: 1-10.

MENDIRATTAS, BHATIAS, JAINS, KAURT, BRAHMACHARIV (2016). Interaction of the chromatin remodeling protein hINO80 with DNA. PLOS ONE 11(7): e0159370.

MISHRASK, KANCHANK, BHARGAVAK(2012). AReview on EZH2 and its Epigenetic Association with Breast Cancer. J. Cancer Res. Update. 1:162-172.

MONDO SJ, DANNEBAUM RO, KUO RC, LOUIE KB, BEWICK AJ, LABUTTI K, HARIDAS S, KUO A, SALAMOV A, AHRENDT SR, et al., (2017). Widespread adenine N6-methylation of active genes in fungi. Nature Genet. 49: 964-968.

MORRISON AJ, SHEN X (2009). Chromatin remodelling beyond transcription: The INO80 and SWR1 complexes. Nature Rev. Molec. Cell Biol. 10: 373-384.

MUÑOZ L, NOMDEDÉU JF, VILLAMOR N, GUARDIA R, COLOMER D, RIBERA JM, TORRES JP, BERLANGA JJ, FERNÁNDEZ C, LLORENTE A, et al., (2003). Acute myeloid leukemia with MLL rearrangements: Clinicobiological features, prognostic impact and value of flow cytometry in the detection of residual leukemic cells. Leukemia 17: 76-82.

NAGARAJAN P, GE Z, SIRBU B, DOUGHTY C, AGUDELO GARCIA PA, SCHLEDERER M, ANNUNZIATO AT, CORTEZ D, KENNER L, PARTHUN MR (2013). Histone Acetyl Transferase 1 Is Essential for Mammalian Development, Genome Stability, and the Processing of Newly Synthesized Histones H3 and H4. PLoS Genet. 9(6): e1003518.

NAN X, MEEHAN RR, BIRD A (1993). Dissection of the methyl-CpG binding domain from the chromosomal protein MeCP2. Nucleic Acid. Res. 21: 4886-4892.

NESTOR CE, OTTAVIANO R, REDDINGTON J, SPROUL D, REINHARDT D, DUNICAN D, KATZ E, DIXON JM, HARRISON DJ, MEEHAN RR (2012). Tissue type is a major modifier of the 5-hydroxymethylcytosine content of human genes. Genome Res. 22: 467-477.

NEUMAN SD, IHRY RJ, GRUETZMACHER KM, BASHIRULLAH A (2014). INO80dependent regression of ecdysone-induced transcriptional responses regulates developmental timing in Drosophila. Dev. Biol. 387: 229-239.

NISHIMOTO N, WATANABE M, WATANABE S, SUGIMOTO N, YUGAWA T, IKURA T, KOIWAI O, KIYONO T, FUJITA M (2012). Heterocomplex formation by Arp4 and -actin is involved in the integrity of the Brg1 chromatin remodeling complex. J. Cell Sci. 125: 3870-3882.

NORLING A, HIRSCHBERG AL, IWARSSON E, WEDELL A, BARBARO M (2013). CBX2 gene analysis in patients with $46, X Y$ and $46, X X$ gonadal disorders of sex development. Fertility Sterility 99(3): 819-826.e3.

OKANO M, BELL DW, HABER DA, LI E (1999). DNA methyltransferases Dnmt3a and Dnmt3b are essential for de novo methylation and mammalian development. Cell 99: 247-257.

OLAVE IA, RECK-PETERSON SL, CRABTREE GR (2002). Nuclear Actin and ActinRelated Proteins in Chromatin Remodeling. Ann. Rev. Biochem. 71: 55-781.

ONDER TT, KARA N, CHERRY A, SINHAAU, ZHU N, BERNT KM, CAHAN P, MARCARCI BO, UNTERNAEHRER J, GUPTA PB, LANDER ES, ARMSTRONG SA, DALEY GQ (2012).Chromatin-modifying enzymes as modulators of reprogramming. Nature 483: 598-602.

OOI SKT, QIU C, BERNSTEIN E, LI K, JIA D, YANG Z, ERDJUMENT-BROMAGE 
H, TEMPST P, LIN SP, ALLIS CD, CHENG X, BESTOR TH (2007). DNMT3L connects unmethylated lysine 4 of histone $\mathrm{H} 3$ to de novo methylation of DNA. Nature 448: 714-717.

ORLANDO DA, GUENTHER MG, FRAMPTON GM, YOUNG RA (2012). CpG island structure and trithorax/polycomb chromatin domains in human cells. Genomics 100: 320-326.

ORLANDO V, JANE EP, CHINWALLA V, HARTE PJ, PARO R (1998). Binding of Trithorax and Polycomb proteins to the bithorax complex: Dynamic changes during early Drosophila embryogenesis. EMBO J. 17: 5141-5150.

ORR BA, HAFFNER MC, NELSON WG, YEGNASUBRAMANIAN S, EBERHART $C G$ (2012). Decreased 5-Hydroxymethylcytosine is associated with neural progenitor phenotype in normal brain and shorter survival in malignant glioma. PLOS ONE 7(7):e41036.

PANIKAR CS, RAJPATHAK SN, ABHYANKAR V, DESHMUKH S, DEOBAGKAR DD (2015). Presence of DNA methyltransferase activity and $\mathrm{CpC}$ methylation in Drosophila melanogaster. Molec. Biol. Rep. 42: 1615-1621.

PAULER FM, SLOANE MA, HUANG R, REGHA K, KOERNER M V., TAMIR I, SOMMERA, ASZODIA, JENUWEIN T, BARLOW DP (2009). H3K27me3 forms BLOCs over silent genes and intergenic regions and specifies a histone banding pattern on a mouse autosomal chromosome. Genome Res. 19: 221-233.

PEIFERM, KARCHF, BENDERW (1987). The bithorax complex: control of segmental identity. Genes Dev. 1:891-898.

RAORA, DHELE N, CHEEMADANS, KETKARA, JAYANDHARAN GR, PALAKODET D, RAMPALLI S (2015). Ezh2 mediated H3K27me3 activity facilitates somatic transition during human pluripotent reprogramming. Sci. Rep. 5:8229.

RATEL D, RAVANAT JL, BERGER F, WION D (2006). N6-methyladenine: The other methylated base of DNA. BioEssays 28: 309-315.

RAZIN A, RIGGS AD (1980). DNA Methylation and gene function. Science 210: 604-610.

RICKELS R, HU D, COLLINGS CK, WOODFIN AR, PIUNTI A, MOHAN M, HERZ HM, KVON E, SHILATIFARD A (2016). An Evolutionary Conserved Epigenetic Mark of Polycomb Response Elements Implemented by Trx/MLL/COMPASS. Molecular Cell 63: 318-328.

RINGROSE L, PARO R (2004). Epigenetic Regulation of Cellular Memory by the Polycomb and Trithorax Group Proteins. Ann. Rev. Genet. 38: 413-443.

RINGROSE L, REHMSMEIER M, DURA JM, PARO R (2003). Genome-wide prediction of polycomb/trithorax response elements in Drosophila melanogaster.Dev. Cell 5: 759-771.

RINN JL, KERTESZ M, WANG JK, SQUAZZO SL, XU X, BRUGMANN SA, GOODNOUGHLH, HELMS JA, FARNHAM PJ, SEGALE, CHANG HY (2007). Functional Demarcation of Active and Silent Chromatin Domains in Human HOX Loci by Noncoding RNAs. Cell 129: 1311-1323.

ROBERT MF, MORIN S, BEAULIEU N, GAUTHIER F, CHUTE IC, BARSALOU A, MACLEOD AR (2003). DNMT1 is required to maintain CpG methylation and aberrant gene silencing in human cancer cells. Nature Genet. 33: 61-65.

ROSE NR, KLOSE RJ (2014). Understanding the relationship between DNA methylation and histone lysine methylation. Biochim. Biophys. Acta - Gene Reg. Mech. 1839: 1362-1372.

RUNGEJS, RAABJR, MAGNUSONT (2018). Identification of Two Distinct Classes of the Human INO80 Complex Genome-Wide. Gene. Genome. Genet. 8: 1095-1102.

SACHAN M, RAMAN R (2008). Developmental methylation of the coding region of c-fos occurs perinatally, stepwise and sequentially in the liver of laboratory mouse. Gene 416: 22-29.

SÁNCHEZ-HERRERO E (1991). Control of the expression of the bithorax complex genes abdominal-A and abdominal-B by cis-regulatory regions in Drosophila embryos.Development 111: 437-49.

SANCHEZ-HERRERO E, AKAM M (1989). Spatially ordered transcription of regulatory DNA in the bithorax complex of Drosophila.Development 107(2):321-9.

SCHEUERMANN JC, DEAYALAALONSO AG, OKTABAK, LY-HARTIG N, MCGINTY RK, FRATERMANS, WILM M, MUIRTW, MULLERJ. (2010). Histone H2Adeubiquitinase activity of the Polycomb repressive complex PR-DUB. Nature 465:243-247.

SCHMITGES FW, PRUSTYAB, FATY M, STÜTZERA, LINGARAJU GM, AIWAZIAN J, SACK R, HESS D, LI L, ZHOU S, et al., (2011). Histone Methylation by PRC2 Is Inhibited by Active Chromatin Marks. Molec. Cell 42: 330-341.

SCHMITZ SU, ALBERT M, MALATESTA M, MOREY L, JOHANSEN J V., BAK M,
TOMMERUP N, ABARRATEGUI I, HELINK (2011). Jarid1b targets genes regulating development and is involved in neural differentiation. EMBO J. 30: 4586-4600.

SCHUETTENGRUBERB, BOURBON HM, DI CROCE L, CAVALLI G (2017). Genome Regulation by Polycomb and Trithorax: 70 Years and Counting. Cell 171: 34-57.

SEGAL E, WIDOM J (2009). From DNA sequence to transcriptional behaviour: A quantitative approach. Nature Rev. Genet. 10: 443-456.

SHAO GB, DING HM, GONG AH (2008). Role of histone methylation in zygotic genome activation in the preimplantation mouse embryo. In Vitro Cell. Dev. Biol - Animal 44: 115-120.

SHI Yujiang, LAN F, MATSON C, MULLIGANP, WHETSTINE JR, COLE PA, CASERO RA, SHI Yang (2004). Histone demethylation mediated by the nuclear amine oxidase homolog LSD1. Cell 119: 941-953.

SHILATIFARD A (2008). Molecular implementation and physiological roles for histone H3 lysine 4 (H3K4) methylation.Curr. Opin. Cell Biol. 20: 341-348.

SHINSKY SA, MONTEITH KE, VIGGIANO S, COSGROVE MS (2015). Biochemical reconstitution and phylogenetic comparison of human SET1 family core complexes involved in histone methylation. J. Biol. Chem. 290: 6361-6375.

SIGRISTCJA, PIRROTTAV (1997). Chromatin insulator elements block the silencing of a target gene by the Drosophila polycomb response element (PRE) but allow trans interactions between PREs on different chromosomes. Genetics 147: 209-221.

SIMON J, CHIANG A, BENDER W, SHIMELL MJ, O'CONNOR M (1993). Elements of the Drosophila bithorax complex that mediate repression by polycomb group products. Dev. Biol. 158: 131-144.

SIMS RJ, CHEN CF, SANTOS-ROSA H, KOUZARIDES T, PATEL SS, REINBERG D (2005). Human but not yeast CHD1 binds directly and selectively to histone H3 methylated at lysine 4 via its tandem chromodomains. J. Biol. Chem. 280 : 41789-41792.

SING A, PANNELL D, KARAISKAKIS A, STURGEON K, DJABALI M, ELLIS J LIPSHITZ HD, CORDES SP (2009). A Vertebrate Polycomb Response Element Governs Segmentation of the Posterior Hindbrain. Cell 138: 885-897.

SINGH NP, MISHRA RK (2015). Specific combinations of boundary element and Polycomb response element are required for the regulation of the Hox genes in Drosophila melanogaster. Mech. Dev. 138: 141-150.

SMEETS HJM, SMITS APT, VERHEIJ CE, THEELEN JPG, WILLEMSEN R, BURGT I van De, HOOGEVEEN AT, OOSTERWIJK JC, OOSTRA BA (1995). Normal phenotype in two brothers with a full FMR1 mutation. Human Molec. Genet. 4: 2103-2108.

ŠMIGOVÁ J, JUDA P, CMARKO D, RAŠKA I (2011).Fine structure of the "pcG body" in human U-2 OS cells established by correlative light-electron microscopy. Nucleus 2: 219-228.

SONG CX, SZULWACH KE, FU Y, DAI Q, YI C, LIX, LIY, CHEN CH, ZHANG W, JIAN $X$, WANG J, ZHANG L, LOONEY TJ, ZHANG B, GODLEY LA, HICKS LM, LAHN BT, JIN P, HE C (2011). Selective chemical labeling reveals the genome-wide distribution of 5-hydroxymethylcytosine. Nature Biotech. 29: 68-75.

SRIVASTAVAA, KUMARAS, MISHRA RK (2018). Vertebrate GAF/ThPOK: emerging functions in chromatin architecture and transcriptional regulation. Cell. Molec. Life Sci. 75: 623-633.

STRUHL G (1981). A gene product required for correct initiation of segmental determination in Drosophila. Nature 293: 36-41.

STRUHL G, AKAM M (1985). Altered distributions of Ultrabithorax transcripts in extra sex combs mutant embryos of Drosophila. EMBO J 4: 3259-3264.

SUBRAMANIAMD, THOMBRER, DHARA, ANANTS (2014). DNAMethyltransferases: A Novel Target for Prevention and Therapy. Front. Oncol. 4. Available at: http:// journal.frontiersin.org/article/10.3389/fonc.2014.00080/abstract

SZERLONG H, HINATAK, VISWANATHANR, ERDJUMENT-BROMAGE H, TEMPST P, CAIRNS BR (2008). The HSA domain binds nuclear actin-related proteins to regulate chromatin-remodeling ATPases. Nature Struct. Molec. Biol. 15:469-476.

TAHILIANI M, KOH KP, SHEN Y, PASTOR WA, BANDUKWALA H, BRUDNO Y, AGARWAL S, IYER LM, LIU DR, ARAVIND L, RAO A (2009).Conversion of 5-methylcytosine to 5-hydroxymethylcytosine in mammalian DNA by MLL partner TET1.Science 324: 930-935.

TAKAHASHI Y -h., WESTFIELD GH, OLESKIE AN, TRIEVEL RC, SHILATIFARD A, SKINIOTIS G (2011).Structural analysis of the core COMPASS family of histone H3K4 methylases from yeast to human.Proc. Natl. Acad. Sci. USA 108: 20526-20531. 
TAKAYAMAS, DHAHBI J, ROBERTSA, MAO G, HEO SJ, PACHTER L, MARTIN DIK, BOFFELLI D (2014). Genome methylation in D. melanogaster is found at specific short motifs and is independent of DNMT2 activity. Genome Res. 24: 821-830.

TAKEDA S, CHEN DY, WESTERGARD TD, FISHER JK, RUBENS JA, SASAGAWA S, KAN JT, KORSMEYER SJ, CHENG EHY, HSIEH JJD (2006). Proteolysis of MLL family proteins is essential for Taspase1-orchestrated cell cycle progression. Genes Dev. 20: 2397-2409.

TAMKUN JW, DEURING R, SCOTTMP, KISSINGERM, PATTATUCCIAM, KAUFMAN TC, KENNISONJA(1992). brahma:Aregulator of Drosophila homeotic genes structurally related to the yeast transcriptional activator SNF2 SWI2. Cell68: 561-572.

TAVARES L, DIMITROVA E, OXLEY D, WEBSTER J, POOT R, DEMMERS J, BEZSTAROSTI K, TAYLOR S, URA H, KOIDE H, WUTZ A, VIDAL M, ELDERKIN S, BROCKDORFF N (2012). RYBP-PRC1 complexes mediate H2A ubiquitylation at polycomb target sites independently of PRC2 and H3K27me3. Cell 148: 664-678.

THOMSON JP, SKENE PJ, SELFRIDGE J, CLOUAIRE T, GUY J, WEBB S, KERR ARW, DEATON A, ANDREWS R, JAMES KD, TURNER DJ, ILLINGWORTH R, BIRD A (2010). CpG islands influence chromatin structure via the CpG-binding protein Cfp1. Nature 464: 1082-1086.

TIE F, BANERJEE R, STRATTON CA, PRASAD-SINHA J, STEPANIK V, ZLOBIN A, DIAZ MO, SCACHERI PC, HARTE PJ (2009). CBP-mediated acetylation of histone H3 lysine 27 antagonizes Drosophila Polycomb silencing. Development 136: 3131-3141.

UEHARA Y, ONO T, KURISHITAA, KOKURYU H, OKADA S (1989). Age-dependent and tissue-specific changes of DNA methylation within and around the $\mathrm{c}$-fos gene in mice. Oncogene. 4: 1023-1028.

UETAKE H, LURIA SE, BURROUS JW (1958). Conversion of somatic antigens in Salmonella by phage infection leading to lysis or lysogeny. Virology 5: 68-91.

VAN HOUDT JKJ, NOWAKOWSKABA, SOUSASB, VAN SCHAIKBDC, SEUNTJENS E, AVONCE N, SIFRIM A, ABDUL-RAHMAN OA, VAN DEN BOOGAARD MJH, BOTTANIA, et al., (2012). Heterozygous missense mutations in SMARCA2 cause Nicolaides-Baraitser syndrome. Nature Genet. 44: 445-449.

VASANTHID, NAGABHUSHANA, MATHARU NK, MISHRARK (2013). A functionally conserved Polycomb response element from mouse HoxD complex responds to heterochromatin factors. Sci. Rep. 3: 1-11.

VLAMING H AND VAN LEEUWEN F (2016). Upstream and downstream of H3K79 methylation by DOT1L. Chromosoma, 125: 593-605

WAN M, LIANG J, XIONG Y, SHI F, ZHANG Y, LU W, HE Q, YANG D, CHEN R, LIU D, BARTON M, SONGYANG Z (2013). The trithorax group protein Ash2l is es- sential for pluripotency and maintaining open chromatin in embryonic stem cells J. Biol. Chem. 288: 5039-5048.

WANG C, LIU X, GAO Y, YANG L, LI C, LIU W, CHEN C, KOU X, ZHAO Y, CHEN J, WANG Y, LE R, WANG H, DUAN T, ZHANG Y, GAO S (2018). Reprogramming of H3K9me3-dependent heterochromatin during mammalian embryo development. Nature Cell Biol. 20: 620-631.

WANG H, WANG L, ERDJUMENT-BROMAGE H, VIDAL M, TEMPST P, JONES RS, ZHANG Y (2004). Role of histone H2A ubiquitination in Polycomb silencing. Nature 431: 873-878.

WANG L, BROWN JL, CAOR, ZHANG Y, KASSIS JA, JONESRS (2004). Hierarchical recruitment of polycomb group silencing complexes. Molec. Cell 14: 637-646.

WANIAH, BOETTIGERAN, SCHORDERETP, ERGUNA, MUNGERC, SADREYEVRI ZHUANG X, KINGSTONRE, FRANCISNJ (2016). Chromatin topology is coupled to Polycomb group protein subnuclear organization. Nature Comm. 7:10291.

WITTKOPPPJ, KALAYG (2012). Cis-regulatory elements: Molecular mechanisms and evolutionary processes underlying divergence. Nature Rev. Genet. 6;13(1):59-69

WOO CJ, KHARCHENKO P V., DAHERON L, PARK PJ, KINGSTON RE (2010). A Region of the Human HOXD Cluster that Confers Polycomb-Group Responsiveness. Cell 140: 99-110.

XIAO C Le, ZHU S, HE M, CHEN D, ZHANG Q, CHEN Y, YU G, LIU J, XIE SQ, LUO F, LIANG Z, WANG DP, BO XC, GU XF, WANG K, YAN GR (2018). N 6 -Methyladenine DNA Modification in the Human Genome. Molec. Cell 71: 306-318.e7.

YU BD, HESS JL, HORNING SE, BROWN GAJ, KORSMEYER SJ (1995). Altered Hox expression and segmental identity in Mll-mutant mice. Nature 378: 505-508.

YUAN W, XU M, HUANG C, LIU N, CHEN S, ZHU B (2011). H3K36 methylation antagonizes PRC2-mediated H3K27 methylation. J. Biol. Chem. 286: 7983-7989.

ZHANG B, ZHENG H, HUANG B, LI W, XIANG Y, PENG X, MING J, WU X, ZHANG $Y, X U Q$, et al., (2016). Allelic reprogramming of the histone modification $\mathrm{H} 3 \mathrm{~K} 4 \mathrm{me} 3$ in early mammalian development. Nature 537: 553-557.

ZHANG G, HUANG H, LIU D, CHENG Y, LIU X, ZHANG W, YIN R, ZHANG D, ZHANG P, LIU J, LI C, LIU B, LUO Y, ZHU Y, ZHANG N, HE S, HE C, WANG H, CHEN D (2015). N6-methyladenine DNA modification in Drosophila. Cell 161: 893-906.

ZHOU T, SUN Y, LI M, DING Y, YIN R, LI Z, XIE Q, BAO S, CAI W (2018). Enhancer of zeste homolog 2-catalysed H3K27 trimethylation plays a key role in acuteon-chronic liver failure via TNF-mediated pathway article. Cell Death Dis. 9: 590

ZINK D, PARO R (1995). Drosophila Polycomb-group regulated chromatin inhibits the accessibility of a trans-activator to its target DNA. EMBO J. 14: 5660-5671. 


\section{Further Related Reading, published previously in the Int. J. Dev. Biol.}

\section{Epigenetic mechanism of FMR1 inactivation in Fragile $\mathbf{X}$ syndrome}

Merav Hecht, Amalia Tabib, Tamar Kahan, Shari Orlanski, Michal Gropp, Yuval Tabach, Ofra Yanuka, Nissim Benvenisty, Ilana Keshet and Howard Cedar

Int. J. Dev. Biol. (2017) 61: 285-292

https://doi.org/10.1387/ijdb.170022hc

\section{Histone deacetylases 1 and 2 are required for brain development} Joanna Jaworska, Malgorzata Ziemka-Nalecz and Teresa Zalewska

Int. J. Dev. Biol. (2015) 59: 171-177

https://doi.org/10.1387/ijdb.150071tz

DNA methylation and its role in the trophoblast cell lineage

Satoshi Tanaka, Momo O. Nakanishi and Kunio Shiota

Int. J. Dev. Biol. (2014) 58: 231-238

https://doi.org/10.1387/ijdb.140053st

\section{Transgenes and their contributions to epigenetic research}

\section{Peter Meyer}

Int. J. Dev. Biol. (2013) 57: 509-515

https://doi.org/10.1387/ijdb.120254pm

Role of epigenetics in the etiology of germ cell cancer

Yvonne G. Van Der Zwan, Hans Stoop, Fernando Rossello,Stefan J. White and Leendert H.J. Looijenga

Int. J. Dev. Biol. (2013) 57: 299-308

https://doi.org/10.1387/ijdb.130017॥
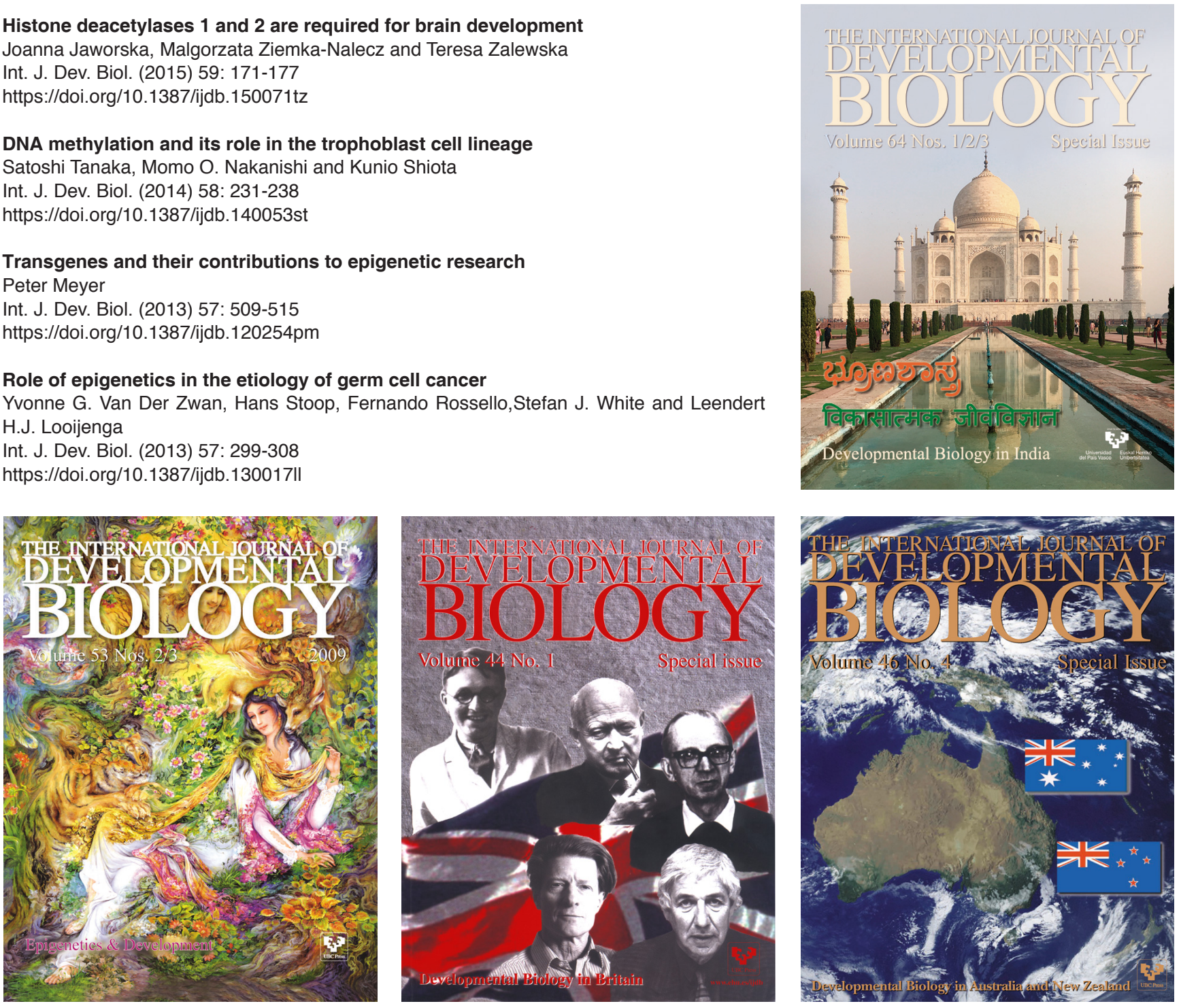